УДК 574(1-925.121)

\title{
ТЕХНОГЕННОЕ ВОЗДЕЙСТВИЕ НА ОКРУЖАЮЩУЮ СРЕДУ В РОССИЙСКОЙ АРКТИКЕ НА ПРИМЕРЕ НОРИЛЬСКОГО ПРОМЫШЛЕННОГО РАЙОНА
}

\author{
Юркевич Николай Викторович1, \\ YurkevichNV2@ipgg.sbras.ru
}

\section{Ельцов Игорь Николаевич1,} YeltsovIN@ipgg.sbras.ru

Гуреев Вадим Николаевич1,2, GureyevVN@ipgg.sbras.ru

\author{
Мазов Николай Алексеевич1, \\ MazovNA@ipgg.sbras.ru
}

Юркевич Наталия Викторовна ${ }^{1}$, YurkevichNV@ipgg.sbras.ru

\section{Еделев Алексей Викторович1, EdelevAV@ipgg.sbras.ru}

1 Институт нефтегазовой геологии и геофизики им. А.А. Трофимука СО РАН, Россия, 630090, г. Новосибирск, пр. Акад. Коптюга, 3.

2 Новосибирский государственный технический университет, Россия, 630087, ул. Немировича-Данченко, 136.

Актуальность работы определяется растущей необходимостью в решении экологических вопросов в арктических регионах Российской Федерации с учетом их особой стратегической значимости для развития страны. Сложность задачи обусловлена, с одной стороны, наличием накопленного экологического ущерба, требующего ликвидации, а с другой - важностью разработки природосберегающих подходов к освоению новых ресурсов в ближайшем будущем.

Цель работы заключается в комплексном анализе состояния экосистемы и ее отдельных компонентов в Норильском промышленном районе как одной из значимых ресурсных территорий российской Арктики. Отдельное внимание уделено методам мониторинга окружающей среды и регулирующим сфреру экологии документам, которые требуют устранения ряда острых противоречий и законодательных пробелов.

Методы исследования включают анализ литературных данных, опубликованных в отечественной и зарубежной печати за последнее десятилетие, по экологическим проблемам российских территорий Арктики в целом и Норильского промышленного района в частности. Для полноты результатов в работе использовался широкий набор библиограсических систем, включая Российский индекс научного цитирования, базу данных Scopus, базу данных «Охрана окружающей среды» рефреративного журнала ВИНИТИ РАН.

Результаты. Выявлены характерные особенности арктических территорий, требующих как нестандартных технологических решений при ведении промышленной деятельности, так и специальных подходов в регулировании и контроле состояния экологии. На примере Норильского промышленного района показаны положительные изменения в экологических аспектах ведения производственной деятельности горно-металлургическим комбинатом, даже несмотря на инцидент с разливом топлива в 2020 г. В то же время предпринимаемых мер пока недостаточно для того, чтобы назвать экологическую обстановку в районе благополучной. Ожидают своего решения проблемы нейтрализации накопленного экологического ущерба. Эфрфективность запланированных мероприятий по улучшению состояния окружающей среды во многом зависит от изменения законодательных актов, пока слабо учитывающих специфику арктических территорий, а также усматривается в большей коллаборации промышленных предприятий как с научным сообществом, так и с проживающим в зоне их активности местным населением.

\section{Ключевые слова:}

Норильский промышленный район, Арктика, экология, накопленный экологический ущерб, мониторинг.

\section{Введение}

Арктика вместе с субарктическими территориями, частично включающими таежные зоны, играет существенную роль в экологическом равновесии Северного полушария: является регулятором кислорода и метана и районом, где проходят глобальные атмосферные процессы [1]. Особое значение имеет лес бореальной зоны, выполняющий важную средообразующую функцию в биосфере и во многом формирую- щий углеродный цикл и климатическую систему Земли [2]. Одновременно с этим природные ресурсы арктических территорий - важный компонент национальных интересов России, а арктические ресурсные корпорации, соответственно, являются приоритетными в национальной экономике Российской Федерации, определяя ее основные тенденции [3]. Значимые для экономики ресурсы Арктики составляют 70 \% от общероссийских: на конец XX в. северные предприятия обеспечивали до 12 \% ВВП России, а в начале XXI в. 
горно-промышленный комплекс российской Арктики на 60-96 \% обеспечивал производство целого ряда цветных и благородных металлов, добычу 80 \% газа и $60 \%$ нефти $[4,5]$.

Поскольку добыча и обработка полезных ископаемых неизбежно сопряжена с нанесением ущерба окружающей среде, возникает необходимость оперативного поиска баланса между соблюдением национальных интересов России и экологическим благополучием арктических территорий. Дополнительной проблемой в построении такого баланса является накопленный экологический ущерб, в основном связанный с последствиями промышленного освоения территорий Севера в советский период. Несмотря на ликвидацию многих источников загрязнения в постсоветское время, арктическое побережье до сих пор остается экологически неблагополучным районом, не менее $15 \%$ площади которого на начало 2010-х гг. имело критический уровень загрязнения $[1,5]$.

Наиболее острые экологические проблемы текущего дня включают рекультивацию нарушенных земель, ликвидацию ущерба, накопленного за предыдущие периоды, нейтрализацию последствий от потепления климата, поскольку возрастает опасность поступления в экосистемы токсичных веществ химических и радиоактивных отходов $[1,5]$. Сохранение и защита природных экосистем, включая ликвидацию последствий от накопленного экологического ущерба, являются в настоящее время приоритетными задачами.

Исследование представляет собой обзор публикаций по теме экологического состояния территорий российской Арктики, и в особенности Норильского промышленного района (НПР) с крупнейшим в регионе предприятием, за последние 12 лет: 2010-2021 гг. Для отбора публикаций использовались как российские, так и международные библиографические указатели, включая Scopus (раздел Earth and Planetary Sciences), реферативный журнал ВИНИТИ РАН (раздел «Охрана окружающей среды») и Российский индекс научного цитирования. В качестве запроса использовались следующие термины на русском и английском языках в различных комбинациях: Арктика, субарктика, Крайний Север, экология, ущерб, Норильск.

\section{Особенности экологического состояния арктических территорий Российской Федерации}

Способность экосистем к самовосстановлению основывается на их адаптационных, буферных и регенерационных качествах. Адаптационные показатели связаны с растительным покровом, буферные - с геолого-морфологическими характеристиками местности, а регенерационные - с климатическими и гидрологическими факторами среды. Особенностью арктических экосистем является снижение всех перечисленных показателей самовосстановления в сравнении с другими климатическими зонами России [6], они чрезвычайно чувствительны как к естественным, так и к антропогенным воздействиям и обладают крайне низкой устойчивостью $[7,8]$.
Свойственные арктическим территориям отрицательные температуры воздуха и земной поверхности, а также длительное стояние снежного покрова приводят к ограниченной подвижности почвенных растворов и циркуляции поверхностных вод, снижают скорость физико-химических реакций в экосистеме и, соответственно, потенциал их самоочищения, связанный с малой скоростью ассимиляции поллютантов и низкой активностью микроорганизмов, разлагающих токсичные вещества. Иными словами, поскольку в микробиоценозах почв лесотундровой зоны высоко содержание органических веществ, но низкая доля элементов минерального питания и большая доля трудноразлагаемых фракций, у микроорганизмов в воде и почве наблюдается слабая способность к трансформации токсичных соединений [9-11].

Растительный покров арктических территорий редкий и отличается низкой скоростью регенерации, большей продолжительностью жизни и медленным циклом смены поколений. Лесным экосистемам присущи замедленные процессы энерго- и массообмена и низкая биологическая продуктивность [10]. Невысокий уровень энерго- и массообмена свойствен обитающим на арктических территориях организмам, что в итоге способствует их высокой чувствительности к неблагоприятным воздействиям и быстрому продвижению экотоксикантов в коротких пищевых цепях в случае их возникновения [12]. Влияние тяжелых металлов на биохимические процессы в растительном покрове в совокупности с отрицательной среднегодовой температурой ведет к замедлению его биоразложения [10].

Таким образом, даже незначительные антропогенные и, реже, естественные воздействия наносят существенный урон арктическим экосистемам, на восстановление которых уходит несколько десятилетий [13]. Особенно губительными оказываются длительные непрерывные воздействия на экосистему, так как они нарушают динамику круговорота элементов и в итоге приводят к новому состоянию или деградации экосистемы. Соответственно, функционирование, продуктивность и устойчивость экосистем и условия их длительного существования зависят от стабильности биогеохимических циклов органических веществ и минеральных элементов, которые контролируются биологическими и геохимическими факторами в их совокупности [10].

\section{Основные источники и причины экологического неблагополучия арктических территорий Российской Федерации}

Освоение природных ресурсов на арктических территориях России разнообразно и зависит от десятков факторов, среди которых присутствуют как естественные, так и антропогенные. Необходимо учитывать тип полезных ископаемых, технологию их разработки, зависимость от транспортной системы. С учетом высокой значимости ресурсов северных территорий для экономики и развития страны неизбежно встает вопрос о потенциальной военной защите этих территорий, предполагающей усиление военного 
присутствия [5]. Таким образом, нанесение ущерба окружающей среде носит комплексный и разнообразный характер, где каждый конкретный случай требует особого детального рассмотрения.

Главными источниками загрязнения являются:

- предприятия горнодобывающей промышленности;

- хвостохранилища ликвидированных предприятий, отвалы пород и шламонакопители, которые резко изменяют структуру крио- и гидросферы [4, 14];

- заброшенные объекты хозяйственной деятельности - метеостанции, аэродромные площадки, пункты противовоздушной обороны, бочки (число которых оценивается в 12 млн единиц [5]);

- промышленные отходы от бурения и эксплуатации скважин: бентонитовая глина, щелочи, цементный раствор, дизельное топливо $[1,15,16]$;

- токсиканты, перенесенные воздушными потоками и речным течением в Арктику из средних широт, причем суровый климат превращает приполярные территории в «холодные ловушки» для различных стойких токсических веществ [11].

Часто отходы хозяйственной деятельности в виде твердых бытовых отходов (стройматериалы, бочки, техника, остатки сооружений, аккумуляторы) не вывозятся и бессистемно скапливаются на необорудованных площадках. На начало 2010-х гг. насчитывалось до 4 млн т промышленного мусора [5].

\section{Антропогенные источники}

Добывающие и обрабатывающие предприятия. Первостепенное значение в особенностях функционирования компаний имеет их тип-ресурсный или обрабатывающий, который определяет специфику производственной деятельности, приоритеты, отношения с НИОКР [3]. Соответственно, различным в зависимости от типа предприятия будет наносимый природе экологический ущерб. Преобладает мнение, что ущерб от добычи полезных ископаемых, то есть недропользования, менее масштабный в сравнении с ущербом от металлургических и перерабатывающих предприятий, к каковым относится горнометаллургический комбинат в НПР [4]. Однако до сих пор представляет проблему выяснение того, какая часть загрязнения вызвана недропользованием, а какая - металлургией. Вредные выбросы предприятий воздействуют практически на все элементы экосистемы Арктики: атмосферу, воду, почву, растительный покров и организмы.

Аварийные ситуации. Поскольку ущерб окружающей среде наносится даже при отлаженной добыче и переработке полезных ископаемых, то гораздо бо́льшие катастрофические последствия для арктических территорий несут аварийные ситуации. Особые риски для арктической биоты приносит загрязнение нефтью, в которой содержатся мутагены, канцерогены, ингибиторы биосинтеза и прочие токсические компоненты; при этом опасность разлива присутствует на всех этапах - добычи, хранения или транспортировки. Источниками же аварий становятся фонтанирование скважин во время разведки или добычи, утечки из трубопроводов либо резервуаров хранения нефтепродуктов, а также аварии при перевозке на автомобилях, по железной дороге или водными видами транспорта [17].

Разливы нефти при низких температурах сохраняются значительно дольше из-за медленной скорости испарения, а попадание нефти в лед или под него делает ее труднодоступной для бактериального разложения. Многолетнемерзлые породы и водные объекты российской Арктики характеризуются невысокой биологической активностью, связанной с низким видовым разнообразием микроорганизмов и их замедленной метаболической активностью [18-20]. Поэтому, по прогнозам, разложение нефти в почве Арктики может занимать несколько десятилетий [17]. И хотя в экспериментах по ликвидации разливов нефти на арктических территориях эффективность доходит до $90 \%$, в реальных условиях среднее значение сбора разлитых нефтепродуктов составляет не более 10-15\% [17].

Военные объекты. Мероприятия по обороне северных границ Российской Федерации, где в советское время было создано три рубежа обороны, наносят российской Арктике экологический ущерб, сопоставимый по масштабам с ущербом от горнопромышленного комплекса [4]. С одной стороны, военная составляющая значительно снизилась с распадом СССР, с другой - при снижении военного контингента заброшенными остались здания, заводы по обслуживанию атомного флота, базы, аэродромы, техника, запчасти, неиспользованное топливо, строительные материалы. Все это внесло основной вклад в накопленный экологический ущерб $[4,5]$. Отдельно необходимо упомянуть отработанные ступени ракет с остатками топлива, запускаемые с космодрома Плесецк: на начало 2010-х гг. их общий объем составлял 3000 т [5]. Вклад в загрязнение на военных объектах также вносят сильнодействующие ядовитые вещества.

В последнее десятилетие техногенная нагрузка от военных объектов вновь возрастает в рамках развертывания Объединенного стратегического командования «Север», что связано с особым статусом северных рубежей и их природных ресурсов в экономике России, а также необходимостью контроля Северного морского пути [6].

Транспорт и логистика. Поскольку северные территории мало заселены - менее 1 \% жителей России [4], а населенные пункты и стратегически важные месторождения рассредоточены, транспортная сеть развита слабо, и в каждом случае требуется разработка уникальных логистических схем как снабжения промышленных и военных объектов, так и последующей транспортировки добытых ресурсов. Как правило, либо реализуются дорогостоящие программы собственного флота, либо создаются хозяйственнотранспортные альянсы [3]. Затраты на логистические цепочки нередко оказываются сопоставимыми с расходами на саму добычу полезных ископаемых. В случае «Норникеля», например, к 2010-м гг. соотношение расходов на добычу и транспортировку составляло 49 и $51 \%$ соответственно [3]. Наибольший ущерб от транспортных систем в НПР принесло строитель- 
ство железной дороги и шоссе между Норильском и Талнахом [4].

Существенный урон растительному покрову российской Арктики наносит гусеничный транспорт, используемый при разведке полезных ископаемых, строительстве трубопроводов и линий электропередач: часто несколько тракторов объединяются в одну группу, которая при передвижении образует глубокие борозды, впоследствии превращающиеся в овраги [15]. Разрушения грунта и растительного покрова - до 50 \% площади - наблюдаются на большинстве участков вдоль газопроводов [15]. При этом даже незначительные нарушения почвенно-растительного покрова вызывают более глубокое оттаивание вечной мерзлоты, оседание грунта и активную эрозию [15].

Кроме инфраструктуры наземного транспорта во второй половине XX в. в Арктике были созданы атомный флот, аэродромы, пункты противовоздушной обороны и радиолокационные станции. Они обслуживают Северный морской путь, связанный как с оборонными мероприятиями, так и с логистическими схемами функционирования горнодобывающих и обрабатывающих предприятий, и тем самым вносят дополнительный вклад в накопленный экологический ущерб. В частности, нерешенной проблемой остаются затопленные в акватории Северного Ледовитого океана суда и ядерные секции кораблей $[21,22]$.

Источники радиоактивного загрязнения. Исторически особый вклад в ухудшение общей экологической обстановки внесли подземные ядерные испытания 1974-1978 гг. с аварийными выбросами радионуклидов на поверхность [1]. Кроме того, в российской Арктике функционируют две атомные электростанции - на Кольском (Кольская, 67²7'55" с.ш. $32^{\circ} 28^{\prime} 59^{\prime \prime}$ в.д.) и Чукотском (Билибинская, 6803'01" с.ш. $166^{\circ} 32^{\prime 2} 20^{\prime \prime}$ в.д.) полуостровах, накопившие большое количество жидких и твердых радиоактивных отходов, а также отработавшее ядерное топливо [5].

\section{Естественные источники}

Климатические изменения. Среди естественных причин, оказывающих заметное влияние на окружающую среду в Арктике, в последние десятилетия доминирует изменение климата. Начиная со второй половины 1970-х гг. оно проявляется в арктической и субарктической зонах России наиболее ярко в сравнении с остальной территорией страны. Средняя температура воздуха в России увеличивается на $0,43{ }^{\circ} \mathrm{C}$ в десятилетие, что 2,5 раза выше среднемирового темпа [23]. В Якутии же с 1966 по 2015 гг. на различных территориях наблюдалось потепление на $1,7-3,1{ }^{\circ} \mathrm{C}$ [1]. Причины потепления включают колебания климатической системы, уровень солнечной радиации, изменения геологической активности Земли, антропогенный фактор.

С одной стороны, потепление может приводить к повышению продуктивности субарктических и арктических экосистем из-за удлинения вегетационного периода и роста среднегодовой температуры многолетнемерзлых пород. Особенно это проявляется в районах термокарстовых озер, поймах рек и тундро- вых ложбинах $[24,25]$. С другой стороны, опасность потепления для арктических экосистем проявляется в учащении наводнений и увеличении их масштабов, поскольку с повышением температуры в атмосфере растет количество водяного пара, влияющего на интенсивность осадков. Наводнения, кроме нанесения прямого ущерба инфраструктуре, влияют на расконсервацию складированных в многолетнемерзлом грунте отходов, которые затем попадают в водные объекты $[1,26]$.

В этих условиях любая авария, подобная произошедшей 29 мая 2020 г. в связи с разливом 21 тыс. м ${ }^{3}$ нефтепродуктов на топливохранилище ТЭЦ-3 Норильско-Таймырской энергетической компании, в сочетании с таянием вечной мерзлоты, усиливает экологические угрозы.

Арктические условия, при которых холодовое воздействие в совокупности с поллютантами приводит к усилению стресса растительности и остановке ее роста [8]. Прочие характерные для Арктики условия, такие как движение льдов, непредсказуемые погодные условия и полярная ночь, во многом повышают риски аварийных ситуаций и затрудняют ликвидацию их последствий $[17,26]$.

\section{Изученность, состав и экологическое состояние ком- понентов окружающей среды Норильского промыш- ленного района}

В Норильском промышленном районе (рисунок) расположен крупнейший металлургический комплекс в Арктике, который одновременно является и самым крупным индустриальным комплексом на Земле, формирующим замкнутую корпоративную территорию с собственной системой тепло- и энергообеспечения, транспортного обеспечения, включая морской, речной флот, железнодорожный транспорт и авиапарк, а также кадровое обеспечение [3, 4, 27]. Владеющая горно-металлургическим комбинатом компания «Норникель» относится, скорее, к обрабатывающим, а не к добывающим корпорациям, и ориентирована прежде всего на поиск рынков сбыта, а не ресурсов, которыми она надежно обеспечена.

«Норникель» работает стационарно уже более 85 лет, что с учетом истощения ресурсов является беспрецедентным сроком на мировом уровне [3]. В НПР сосредоточены предприятия с наибольшим в мире производством палладия и никеля, а также одним из наиболее крупных производств платины и меди. По состоянию на середину 2010-х гг. НПР обеспечивал 39 \% мирового производства палладия, от 14 до $20 \%$ никеля, $12 \%$ родия, $11 \%$ платины, $6 \%$ кобальта и $2 \%$ меди $[28,29]$. К производимым «Норникелем» продуктам тяжелой металлургии также относятся техническая сера, технический селен, катодная медь, концентраты драгоценных металлов, никелевый файнштейн, первичный никель, никелевая карбонильная дробь, никелевый карбонильный порошок, никелевый концентрат, кобальтовый концентрат, электролитный кобальт, техническая серная кислота, сульфат натрия, хлорид натрия, никелевый штейн и медный штейн [7]. 


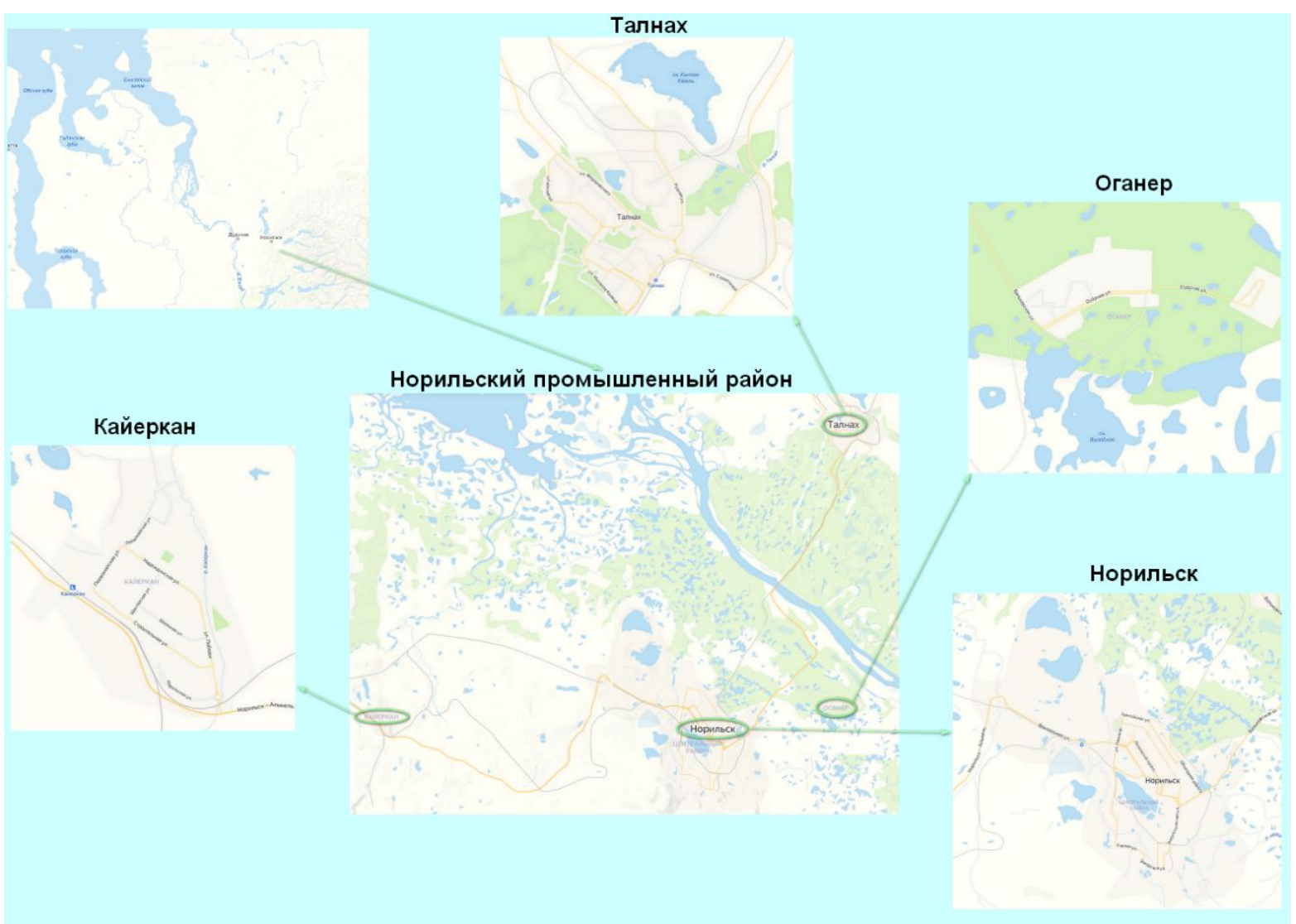

Рисунок. Схема Норильского промышленного района

Figure. Scheme of the Norilsk Industrial Area

Столь широкий ряд продукции обусловливает и разнообразие вредных выбросов с предприятий НПР, а общая масса отходов составляет более 1 млрд т и занимает свыше 6 тыс. га [5]. На предприятия НПР приходится $78 \%$ вредных выбросов Красноярского края и $10 \%$ - Российской Федерации $[9,23]$. Наиболее вредоносными поллютантами являются сера и ряд тяжелых металлов: медь, никель, кобальт и свинец. Из-за различий в путях распространения поллютантов четкие пространственные корреляции между концентрациями серы и тяжелых металлов, с одной стороны, и степенью повреждений компонентов экосистем (например, растительности, почвы или воды) - с другой - отсутствуют [30], поскольку пылевые частицы выпадают сразу, газообразные же вещества (сера) вначале поднимаются вверх и осаждаются за 30-километровым радиусом от источника эмиссии, где уже отсутствуют критические значения по тяжелым металлам [9].

Диоксид серы вносит наибольший вклад в уровень загрязнения окружающей среды НПР: в последние годы на его долю приходится 96-98 \% всех выбросов $[2,31]$. Сера выпадает на расположенные рядом с источниками территории в количестве 570-17000 кг на км $^{2}$ (ср. с фоновым значением 50 кг). Выбросы меди в зоне преимущественного загрязнения за год достигают от 18 до 2700 кг (средние значения в зонах с низкой пылевой нагрузкой - от 0,05 до 56 кг). Расчеты для свинца на загрязненных территориях: от 1 до 25 кг (средние значения на незагрязненных территориях - от 0,02 до 1,5 кг на км²). Суммарные пылевые нагрузки в середине 2000-х гг. составляли от 43 до 47 тыс. т [32].

Негативное воздействие предприятий НПР на окружающую среду в основном затрагивает близлежащие территории и носит локальный характер - по линиям ветров. Экологическое состояние НПР на текущий момент оценивается как кризисное, но не катастрофическое, что предполагает возможность восстановления природной среды [4]. Тем не менее часть нарушенных экосистем находится на необратимых стадиях вырождения [33]. В меньшей степени влияние НПР касается экологии Сибири в целом. Вопрос же о том, оказывает ли горно-металлургический комбинат серьезное воздействие на экологическое состояние обширной территории Арктики, остается спорным, поскольку исследований мало, а их данные разнородны [34]. В отдельных работах указывается на регистрацию выбросов предприятий НПР (преимущественно в виде пыли и аэрозолей) в акваториях российских арктических морей, в Центральной Арктике и в более отдаленных районах американского материка, включая Канаду, куда поллютанты могли проникнуть через Северный Полюс $[4,35]$. В то же время подробный анализ информации о состоянии снега, почвы, водоемов и растительного покрова в НПР и близлежащих районах показал незначительное прямое влияние на объекты окружающей среды Арктики [34]. Отсутствие надежных свидетельств о переносе вредных веществ на значительные расстояния подтверждается и в других исследованиях $[36,37]$. 
Влияние локальных выбросов предприятий НПР, прежде всего воздушных, или аэротехногенных, приходится на широкий ряд природных компонентов, прежде всего атмосферу, через которую впоследствии прямо или косвенно заражаются воды рек и водоемов, почва, что приводит к деградации растительности и соответственно развитию заболеваний животных и человека на территории до 200 км от промышленной зоны, особенно в случае с тяжелыми металлами, которые, попадая в окружающую среду, включаются в биогеохимические процессы и накапливаются в живых организмах $[9,12]$. Например, в озере Пясино у 100 \% рыб обнаружены аномалии внутренних органов [38].

Загрязнения атмосферы в виде пыли осаждаются на подстилающую поверхность на расстоянии до 7 км от источников выбросов; поллютанты в виде аэрозолей и газов (например, водорастворимые формы серы) распространяются на территорию до 400 км [32]. Вода кроме загрязнения через атмосферу подвергается загрязнению нагретыми сбросами сточных вод с токсичными компонентами и аварийными сбросами из пульпопроводов.

Одним из последних случаев нанесения существенного урона экосистеме вокруг НПР в результате аварии стал разлив 21 тыс. м ${ }^{3}$ (17 тыс. т) нефтепродуктов на ТЭЦ-3 29 мая 2020 г. Авария произошла в результате просадки бетонного фундамента под резервуаром топливного бака № 5. При этом гипотезу о влиянии на просадку процессов таяния вечной мерзлоты ряд исследователей отвергает [39, 40]. Шесть тысяч тонн нефтепродуктов впиталось в грунт, а остальные через реки Амбарная и Далдыкан попали в озеро Пясино, загрязнив в общей сложности 180 тыс. $\mathrm{m}^{2}[13,40]$. Следует отметить, что значительная часть дизельного топлива из реки Амбарной попала в протоки и мелкие озера, чему способствовало отсутствие паводков и снега, а поверхностные загрязнения в основном удалось собрать в первые две недели и, таким образом, не допустить масштабного загрязнения озера Пясино [41].

Ниже представлено текущее состояние основных компонентов экологической системы НПР

\section{Атмоссрера}

Наиболее интенсивному загрязнению, связанному с выбросами от добычи и переработки в НПР сульфидных руд цветных металлов, подвергается атмосфера, а основным источником загрязнения являются дымовые и газовые выбросы от плавильных заводов [34]. Отдельный вклад в загрязнение атмосферы НПР, оцениваемый на уровне $10 \%$, вносит автотранспорт, особенно в зимний период, что также способствует аккумулированию вредных примесей в приземной атмосфере [23].

К поллютантам атмосферы НПР относится широкий спектр загрязняющих веществ: угарный газ, диоксид серы, оксиды азота, летучие органические соединения; парниковые газы - углекислый газ, метан и оксид азота; а также аэрозоли, к которым относится черный углерод (сажа), образующиеся либо при сжи- гании топлива, либо при производственной деятельности [23]. На газообразный сернистый ангидрид, образуемый при окислении сульфидной серы при обжиге руды, приходится до 96-98 \% выбросов [2, 31]. В 2019 г. выпадение серы превышало критическое значение в 5,2 раза и составляло 10,4 т на км ${ }^{2}$ в год, что было наивысшим показателем в России [23]. Дымовой шлейф от горно-металлургического комбината достигает 120 км в длину и 40 км в ширину [33], а качественное изменение концентрации серы при активном переходе газа в частицу фиксируется на расстоянии 60-100 км от источника выбросов [31].

Оксид и диоксид азота играют важную роль в фотохимических процессах в тропосфере и стратосфере и вызывают образование фотохимического смога и высоких концентраций тропосферного озона [23]. Как следствие, выбросы аэрозолей существенно снижают прозрачность атмосферы, а также воздействуют на формирование и структуру облаков, которые уменьшают поверхностное излучение и вызывают рассеивание света.

При оценке степени загрязнения атмосферы НПР важным представляется понимание особенностей ее циркуляции, обусловленной рельефом местности. Преобладает юго-восточная роза ветров, а критическая концентрация выбросов, по разным оценкам, наблюдается в южном [9], юго-восточном [29] и югозападном [34] направлениях от источников эмиссии. Доминирующее направление ветра оказывается напрямую связано с зонами, наиболее сильно пострадавшими от загрязнения. Геоморфологические особенности рельефа НПР формируют горизонтальнонеоднородное и изменчивое по высоте поле ветра, предотвращающее распространение загрязнения на север и в целом локализующее загрязнение экосистем [34]. К настоящему моменту восстановлены поля длительных выпадений пыли и тяжелых металлов, а также намечены возможности установления связей аэрозольного загрязнения с яркостными характеристиками снегового покрова [42].

Исследования атмосферы дают ключ к пониманию путей загрязнения прочих компонентов природной среды НПР и Арктики в целом. Динамический анализ антропогенного влияния НПР, проводимый Росгидрометом в течение 27 лет, позволил оценить закономерности распространения в атмосфере тяжелых металлов, осаждающихся на подстилающую поверхность. Изменения антропогенной нагрузки через атмосферу оказались связаны с уменьшением вредных выбросов, а также с изменением процессов циркуляции воздушных масс во времени, которые могут оказывать эффект, сопоставимый с эффектом от снижения вредных выбросов [35]. В совокупности эти два процесса привели к снижению уровня загрязнения в 2000-х гг. в сравнении с 1990-ми гг. [34, 35]. В 2010-х гг. также отмечено снижение загрязнения атмосферы на $8 \%$ [7]. Однако, несмотря на улучшившееся за последние 30 лет качество воздуха в российской Арктике, уровень загрязнения в НПР все еще остается очень высоким [23]. 


\section{Снежный покров}

Отличительной характеристикой снежного покрова НПР и Арктики в целом является большая продолжительность снежного периода и способность накапливать множество поллютантов из нижних слоев атмосферы. Другой важной особенностью снежного покрова является то, что при таянии он превращается в источник вторичного загрязнения остальных компонентов экосистемы: тяжелые металлы или нефтепродукты при таянии через грунтовые воды или речной сток могут попадать в море, где, увлекаемые течением, распространяются на значительные расстояния в акватории [17]. Кроме того, черный углерод, оседая на белоснежных арктических покровах, изменяет их отражательные свойства, а оксиды азота и оксид серы приводят к закислению атмосферных осадков, что в целом способствует преждевременному таянию снежного покрова и ледников [23].

Интенсивность загрязнения снежного покрова вокруг НПР во многом зависит от метеорологических условий, связанных со скоростью и направлением ветра в различные сезоны, а также хорошо коррелирует с составом атмосферы НПР [32]. Химические элементы поступают в снежный покров различными путями: с атмосферными осадками, путем поглощения из атмосферы газов и водорастворимых аэрозолей, путем взаимодействия с твердыми пылевыми частицами [32].

Картирование загрязнений снежного покрова вокруг НПР показывает, что наиболее сильно загрязняет снег дефляционная пыль с промышленных объектов, в меньшей мере - промышленные выбросы в атмосферу, за чем следует естественная дефляция. В 2010-х гг. количество пыли в снеге двукратно превышало объем пыли, выбрасываемой предприятиями «Норникеля», что говорит о неучтенном вкладе иных источников, включая автотранспорт и продукты дефляции с карьеров и хвостохранилищ. Химический состав техногенной пыли в снежном покрове характеризуется высоким содержанием в нем серы, тогда как в природной пыли больше кальция и цинка природного происхождения [32].

Промышленная пыль осаждается в основном в радиусе 40 км, 90 \% приходится на семикилометровую зону вокруг источников эмиссии. На отдаленные от Норильска северные территории полуострова Таймыр (100 км и более от источника загрязнения) предприятия НПР, по-видимому, не оказывают существенного негативного воздействия, что показано по исследованию уровня $\mathrm{pH}$ снега [34]. Аналогичная ситуация с тенденцией к снижению загрязнения в районе Норильска выявлена по анализу концентрации серы в снегу. Концентрации тяжелых металлов, таких как медь, цинк и никель, также были высокими в НПР, но низкими в других прилегающих регионах [34].

Таким образом, исследование снежного покрова обладает высокой информативностью при выявлении общего техногенного загрязнения окружающей среды.

\section{Вода}

Загрязнение рек и водоемов представляет собой наиболее острую экологическую проблему. В НПР оно происходит при таянии снегов, воздействии сточных вод, при аварийных ситуациях (например, разливе вредных веществ), а также через осаждение вредных примесей из атмосферы, притом что воздушный перенос металлов распространяется до 30 км [38]. Элементный состав вод чрезвычайно сложен и определяется множеством параметров, включающих химические, физические, геологические и биологические. Водные системы являются коллекторами загрязнений и отражают изменения геохимических циклов элементов под влиянием антропогенных факторов [12].

На начало XXI в. гидроэкологическое состояние практически всех водных объектов НПР выходило за пределы нормы по удельному комбинаторному индексу загрязненности воды (ведомственному нормативу Росгидромета), хотя и не было катастрофическим [43]. На территории отмечается наибольшая в арктической Сибири минерализация, проявляющаяся в повышенных концентрациях никеля и меди. Величина $\mathrm{pH}$ характеризует озера как щелочные, низкая цветность является индикатором присутствия соединений железа; кроме того, выявлено высокое содержание сульфатов, что подтверждает ключевой фактор антропогенного вклада в элементный состав вод [12]. Воздушный перенос микроэлементов хотя и не приводит к существенному загрязнению вод, но повышает концентрацию многих элементов. Глобальное же нарастание содержаний элементов в водах суши, даже при соответствии предельно допустимым концентрациям (ПДК), приводит к их включению в биогеохимические циклы и токсическому накоплению в живых организмах [12].

Тяжелые металлы накапливаются прежде всего в верхних слоях донных осадков, могут переходить в иловую и придонную воду, создавая источник вторичного загрязнения водоема: загрязненный осадочный материал быстро достигает дна, особенно в прибрежных и мелководных частях водоемов, а затем загрязнение переходит в иловую и наддонную воду [38]

Важным объектом исследования уровня загрязнения водной системы НПР являются болота. Биогеохимические исследования, в том числе оценивающие наличие металлов в нетронутых водно-болотных угодьях НПР, как и российской части Арктики в целом, не проводились до начала 1990-х гг. В одной из первых работ оценивались концентрации кадмия, свинца, цинка и меди на нетронутых водно-болотных угодьях: для отдаленных от Норильска районах Таймыра было показано соответствие содержания тяжелых металлов в водоемах фоновым уровням и, таким образом, отсутствие влияния НПР на водоемы нетронутых территорий [36]. Результаты оценки вод по тому же набору элементов в водоемах вблизи НПР в конце $\mathrm{XX}$ в. показали, что их концентрация могла в 1000 раз превышать фоновые уровни, определенные для незагрязненных территорий [37].

Данные 2019 г. с оценкой органолептических и химических показателей пяти районов НПР продемонстрировали незначительное локальное воздействие промышленности на состояние водных источников [44]. Наиболее загрязненным водоемом НПР 
является озеро Пясино, в которое направлены стоки рек и загрязняющих вод Норильска. В меньшей мере загрязнению подвергнуты озера Лама и Пуринские. Река Пясина, вытекающая из озера Пясино, является потенциальным поставщиком загрязняющих веществ в Карское море и воды океана. Особенно актуально это в случае аварийных ситуаций, подобных случившейся на ТЭЦ-3 в 2020 г. [45]. Стоит отметить загрязненность вод Карского моря тяжелыми металлами и нефтепродуктами и безотносительно деятельности НПР - под воздействием других предприятий или военных объектов. Основную роль в формировании состава воды и донных отложений играют впадающие в Карское море Обь и Енисей, водосборы которых охватывают территории со значительными антропогенными выбросами тяжелых металлов [46]. При этом речные потоки в 10 раз интенсивнее атмосферных, которые, тем не менее, также играют значимую роль в переносе тяжелых металлов в тех частях Карского моря, где влияние Оби и Енисея уже незначительно [47, 48]. Определенный вклад в загрязнение прибрежных вод вносят объекты накопленного экологического ущерба от прошлой военной деятельности на островах Карского моря [16, 49].

По результатам исследования, проведенного авторами и их коллегами из ИНГГ СО РАН в рамках Большой Норильской Экспедиции СО РАН в 2020 г., для более десятка водоемов (оз. Пясино, оз. Лама, оз. Мелкое и др.) и водотоков (руч. Надеждинский, р. Далдыкан, р. Амбарная, р. Пясина, р. Болгохтох, р. Купец и др.), расположенных в 10-15километровой зоне воздействия НПР, установлены превышения в содержании металлов (медь, цинк, железо, никель, кобальт, алюминий, кадмий, молибден и др.), сульфатов, нефтепродуктов над нормативными ПДК вредных веществ в водах водных объектов рыбохозяйственного значения. В водных объектах, находящихся в непосредственной близи (сотни метров) промышленных предприятий, превышения могут достигать тысяч раз (по меди, никелю, железу, алюминию). При удалении концентрации веществ резко падают, с превышением ПДК от нескольких единиц до десятков раз. Также содержание выше нормативов ПДКрх (больше в 2-3 раза для меди, цинка, железа) обнаружены в водных объектах, условно относящихся к неподвергающимся техногенному воздействию.

\section{Почва}

Почвы НПР относятся к тундровым, развивающимся на почвообразующих породах морского и ледникового происхождения, и представлены в основном криоземами, а также подбурами, торфяно-криоземами, грануземами и литоземами $[9,50]$. Они разделены на три зоны: 1) Норильск, где почвы загрязнены шлаками; 2) пригород на расстоянии до 15 км, где загрязнение происходит от аэрозолей; 3) фоновая зона до 100 км от города [51]. Наибольшая площадь загрязнения наблюдается в 30-километровом радиусе от источников, а наивысшие концентрации, как и в случае со снежным покровом, наблюдаются по розе ветров от источников вредных выбросов. Уровень содержания никеля и меди - приоритетных загрязнителей почв наиболее высоким оказался в массивах Оганер и Талнах - более 200 мг/кг. Максимальное содержание серы в наиболее приближенных к источникам эмиссии почвах - более 7000 мг/кг, что превышает фоновое значение в 8 раз. В торфяниках на расстоянии 45-70 км от источников выбросов концентрация серы превышает фон в 2 раза. На расстоянии в 85 км в торфяных залежах загрязнение серой не фиксируется [52].

Сера и металлы активно накапливаются в верхних 5 см торфяных залежей (с максимумом в поверхностном горизонте от 0 до 2 см) при прохождении техногенных потоков сквозь торфяную толщу в пределах 30 см [52]. Под влиянием прямых или косвенных воздействий предприятий НПР в свойствах почв происходят физические и химические изменения: утрачиваются элементы питания, накапливаются поллютанты, в особенности тяжелые металлы, а присутствие серы ведет к подкислению почв $[9,52]$. Поступление в почву тяжелых металлов, наиболее губительных для микробоценозов, происходит в виде сухих и влажных атмосферных выпадений, с растительным опадом либо через поверхностный сток. Накапливаясь в значительных количествах, поллютанты прежде всего воздействуют на жизнедеятельность почвенных микроорганизмов [9].

Кроме поллютантов к негативным изменениям в почвах приводит гибель деревьев и смена растительности, также вызванные воздействием на них загрязняющих веществ горно-металлургического комбината. Изменения растительного покрова ведут к снижению аккумуляции органических веществ в почве, падению интенсивности обмена веществом и энергией между компонентами экосистемы, изменению гидротермического режима, далее к смене типов почв и, как следствие, к увеличению глубины сезонного оттаивания многолетней мерзлоты и общему нарушению устойчивости экосистемы $[9,10]$.

Значительные структурно-функциональные нарушения микробного комплекса почвы связаны с полным отмиранием растительного покрова. Мертвый растительный материал становится сорбционным, седиментационным и механическим барьером с высокой концентрацией тяжелых металлов. Численность микроорганизмов, соответственно, становится намного ниже в сравнении с незагрязненными почвами, а их функциональность в шесть раз ниже, что вызвано замедлением метаболизма микроорганизмов под действием тяжелых металлов [9]. В конечном итоге, несмотря на определенную приспособляемость микроорганизмов к постоянному поступлению агрессивных поллютантов, структурно-функциональные нарушения почв ведут к замедлению круговорота биогенных элементов, а также снижают устойчивость почв к загрязнению.

Аналогично водным объектам НПР, почвы напрямую подвержены загрязнению в случае аварийных ситуаций, как в случае с уже описанной аварией на ТЭЦ-3 Норильска.

\section{Растительный покров}

В зоне действия предприятий НПР находятся лесотундровые, тундровые и болотные экосистемы. 
С учетом субарктического климата с холодной зимой и коротким летом продолжительность вегетационного периода $\left(+5^{\circ} \mathrm{C}\right)$ составляет $80-90$ дней, а период интенсивного роста $\left(+10{ }^{\circ} \mathrm{C}\right)-60$ дней [9].

Начиная с 1930-х гг., на которые приходится начало интенсивной индустриализации, загрязнение от НПР затронуло большие площади тайги и тундры $[2,53]$. Следует отметить противоречивость в оценке площади поврежденной растительности, степени тяжести повреждений, а также недостаточную изученность воздействия промышленного загрязнения на функционирование и продуктивность растительного покрова [2]. По разным оценкам, максимальная площадь поражения за время работы горнометаллургического комбината составила от 500 тыс. [8] до 7 млн га [4].

По степени нарушенности выделяют сильно, умеренно и слабо нарушенные фитоценозы, а также условно фоновые территории [50]. Наибольшая деградация растительности наблюдается на непосредственно прилегающей к Норильску территории, а также, аналогично снежному покрову и почве, в зоне распространения воздушно-пылевого шлейфа от выбросов. В зоне наиболее интенсивного антропогенного воздействия наблюдаются участки полностью уничтоженной растительности - прежде всего это южная, юго-восточная и северо-восточная области от Норильска [34]. Зона средних нарушений приходится на область распространения шлейфа за исключением его центральной части и выражается пониженным флористическим разнообразием растительных сообществ.

В НПР отмечается пониженное видовое разнообразие во всех систематических группах высших и низших растений, притом что постоянные промышленные выбросы не дают растительным покровам перейти в стадию восстановления [33]. При этом растения по-разному реагируют на токсические выбросы горно-металлургического комбината. Наиболее приспособленными оказались растения с быстрой регенерацией - злаки, ивы и некоторые виды разнотравья [33]. Напротив, водоросли, медленно регенерирующие мхи и лишайники, а также арктические виды цветковых растений наиболее чувствительны к химическому загрязнению. Первыми из экосистем исчезают лишайники, что приводит к деградации тундровых систем [33]. В свою очередь, сокращение мхов и лишайников существенно влияет на сокращение оленьих пастбищ и популяции северных оленей [15].

Антропогенное воздействие на растительный покров можно отслеживать по скорости деградации лесов, которая хорошо согласуется с динамикой техногенной нагрузки на экосистему НПР. Согласно работе А.В. Кирдянова с соавторами [8], леса подразделяются на ослабленные, сильно ослабленные, усыхающие и погибшие. Гибель отдельных деревьев началась в 1940-х гг. В 1960-е гг. начали работать новые производства, трехкратно увеличился объем продукции металлов, были построены высокие трубы, что в свою очередь увеличило площадь загрязнения. С этого времени фиксируется массовая гибель деревьев. В 1970-х гг. наблюдается полное разрушение древосто- ев и всплеск гибели лиственницы [8]. К 1990-м гг. на расстоянии 120 км от Норильска наблюдалось $50 \%$-е уничтожение лиственного леса, а в 7-50-километровой зоне - $100 \%$-ное уничтожение [15]

В 1990-х - начале 2000-х гг. отмечено возобновление роста колец деревьев, возможно, связанное со снижением техногенной нагрузки. Всего с 1960-х гг. с подветренной стороны НПР погибло до 24 тыс. км ${ }^{2}$ леса, что совпало с резким увеличением концентрации серы, меди и никеля в атмосфере [2]. Никель признан наиболее высокотоксичным для растительности, в особенности для высших растений - березовых и лиственничных лесов, ивы, ольхи и прочих кустарников [52]. Тяжелые металлы в совокупности с серой в виде кислотных дождей поражают хвою деревьев. Это приводит к нарушению фотосинтеза, а также росту уязвимости деревьев к насекомым и грибам. Дополнительным фактором поражения растительного покрова является почва, подверженная воздействую поллютантов (прежде всего серы) [8].

Перед гибелью деревьев отмечается деградация их роста [8], и именно промышленный фактор, повидимому, объясняет «проблему дивергенции» в дендрохронологии: начиная с 1960-х гг. наблюдаются расхождения между летним ростом температуры и реальным приростом древесных растений. Высказывается мнение, что повышенная концентрация аэрозолей из-за выбросов снижает чувствительность деревьев к температуре, тем самым замедляя их рост [2]. По текущим прогнозам, при сохранении существующих темпов загрязнения зона полностью погибших лесов, охватывающая сегодня 86 км от Норильска, будет расширяться [8].

\section{Основные современные методы мониторинга}

Главная задача мониторинга - точная оценка уровня повреждений всех компонентов экосистемы, которая в числе прочего может использоваться для выработки экологических нормативов по допустимым уровням выбросов вредных веществ. Применяемые при мониторинге экологического состояния НПР подходы и методы напрямую зависят от анализируемых объектов и их характеристик. Задействуется широкий методологический и технический инструментарий различных дисциплин, часто сочетающий разнообразие подходов для верификации и повышения достоверности результатов.

В широком смысле для прямого наблюдения за большинством компонентов экосистем, рассмотренных выше, применяются либо наземные, либо дистанционные технологии, а для прогнозирования экологических процессов, последствий возможных аварий широко применяются теоретические модели.

В наземных измерениях методологической основой является сравнение наблюдаемых уровней концентрации поллютантов с региональным геохимическим фоном. Кроме того, могут применяться гигиенические эталоны - предельно или относительно допустимые концентрации вредных веществ. Поскольку высокие уровни концентрации поллютантов могут быть вызваны различными причинами, для выявления 
антропогенного характера загрязнения используется анализ величин их концентрации в зависимости от удаленности от источника загрязнения [50]. Выявление аномалий, обусловленных промышленной деятельностью в НПР, при которых концентрации различных элементов превышают фоновые значения, является одной из наиболее значимых экологогеохимических задач [52]. Коэффициент аномальности, то есть отношение среднего содержания элемента к природной норме - геохимическому фону, является методологической основой выявления загрязнения [52].

С разработкой автоматизированных систем учета важным средством мониторинга становятся стационарные посты с различными датчиками, круглосуточно и в режиме реального времени позволяющими отслеживать уровень загрязнения природных компонентов, в том числе неспециалистам, что усиливает общественный экологический контроль [54]. Ниже приведены некоторые примеры наземных наблюдений за отдельными компонентами экосистемы НПР, включая атмосферу, воду, почву и растительный покров.

Концентрация вредных выбросов в атмосферу рассчитывается по оценке баланса массы пассивной и химически активной примесей, которые попадают в атмосферу из стационарного точечного источника. При этом для достоверной оценки экологического состояния атмосферы недостаточно просто выявлять степень загрязненности воздуха: следует также учитывать различия в процессах осаждения примесей на поверхность [35].

Для анализа экологического состояния почв и их химического состава используются энергодисперсионные рентгенофлуоресцентные анализаторы: в традиционном рентгенофлуоресцентном режиме определяются тяжелые металлы, тогда как для выявления сверхтяжелых металлов применяется рентгенорадиометрический режим. При анализе проб почвы, воды и донных отложений водоемов в полевых условиях применяются многопараметрические измерители, способные в экспресс-режиме оценивать широкий ряд характеристик, таких как $\mathrm{pH}$, окислительновосстановительный потенциал, растворенный кислород, проводимость, температура, соленость. Определение элементного состава проб воды, почв и донных отложений проводится при помощи массспектрометрии с индуктивно-связанной плазмой (ИСП-МС), обладающей высокой чувствительностью к определению металлов и примесных элементов. Другими распространенными методами определения элементного состава образцов являются атомноэмиссионная спектрометрия (АЭС) и атомноабсорбционная спектрометрия (ААС). Биологический потенциал почвы анализируется при исследовании свойств микроорганизмов, которые являются оперативными и чувствительными маркерами. Микробные комплексы быстро и отчетливо реагируют на антропогенные факторы, позволяя, таким образом, вести их мониторинг и отслеживать структурнофункциональные изменения в биологическом круго- вороте [9]. Предварительная подготовка проб и фиксация наличия в них поллютантов определяется по ГОСТам и протоколам, подробно изложенным в различных методиках определения массовой концентрации элементов $[16,55]$.

Для определения концентраций элементов в воде может использоваться масс-спектрометрия, а для оценки влияния показателей водной среды на распределение элементов - анализ многофакторного шкалирования [12]. Эффективным методом определения техногенных загрязнений является фактор обогащения (ER), применяемый для оценки загрязнения почвы и водных объектов и рассматриваемый как отношение содержания металла в исследуемом образце к референтному металлу в этом же образце в сравнении с таковым отношением металлов в фоновых породах [12].

В анализе деградации растительных покровов часто используется сравнительный анализ величины радиального прироста деревьев с перекрестной датировкой погодичной изменчивости ширины годичных колец деревьев из одинаковых дендроклиматологических районов и жизненного состояния растительности [8]. Проводится оценка биологического разнообразия с составлением геоботанических карт [33]. Оценка индекса хлорофилла легла в основу составления карт повреждения растительного покрова вокруг НПР с учетом уровня поражений, а полученные спектрометрией данные показали хорошую корреляцию с оценкой концентрации серы в хвое деревьев [56]. Для вычисления содержания серы и тяжелых металлов в различных компонентах экосистемы и анализа временной динамики ее состояния могут применяться пространственные регрессионные модели [57].

Значительное место в исследовании загрязнения отдельных компонентов экосистемы занимают методы дистанционного зондирования - спутникового и самолетного с использованием самолетовлабораторий [31]. Спектр таких методов достаточно широк и применим к различным метеоусловиям, временам года и типам решаемых задач. В дистанционном наблюдении за территорией НПР часто используются аппараты Европейского космического агентства, которые позволяют проводить мониторинг наземных экосистем, в том числе количественную оценку повреждения растительного покрова, в режиме реального времени с созданием соответствующих карт [56, 57]. Карты экологического риска впоследствии могут использоваться для контроля опасных процессов в экосистемах, входящих в зоны крупных промышленных объектов в Арктике.

В частности, спутниковое зондирование было успешно применено при мониторинге причин аварии на ТЭЦ-3 Норильска в 2020 г. Интерферограммы по снимкам земных покровов позволили выполнить мониторинг состояния топливных резервуаров и прилегающей к ним территории. По полученным данным группа исследователей сделала вывод, что разгерметизация резервуара не была вызвана смещением отражающей поверхности исследуемой территории вследствие таяния вечной мерзлоты [39]. Отметим, 
что данные со спутников дополнительно могут использоваться для смежных целей: в частности, для мониторинга хода работ по ликвидации последствий экологических катастроф. Так, на ТЭЦ-3 эффективность восстановительных работ оценивалась по анализу спутниковых снимков, последовательно отображающих следы транспорта ликвидационных служб, появление емкостей для сбора разлитой жидкости и др. [41].

В недавних спутниковых наблюдениях за уровнем серы в НПР использовались инфракрасный интерферометр для зондирования атмосферы и тепловое инфракрасное зондирование, которые показали перспективность для измерения приповерхностного загрязнения серой $[58,59]$. Спутниковое зондирование активно применяется для определения уровня углекислого газа в атмосфере арктических территорий Российской Федерации [60].

Широко задействуются методы математического моделирования. Так, при аварийных ситуациях, например, разливах нефти, возможно использование гидродинамического моделирования процессов эволюции нефтяного разлива на земной поверхности, позволяющего оценить масштабы загрязнения [17]. Набирают популярность подходы на основе обратных задач, включающих совместное применение математических моделей по переносу примесей с имеющимися экспериментальными данными. Обратная задача например, решалась в исследовании особенностей атмосферной циркуляции в НПР [42].

Несмотря на широкий и сложный инструментарий мониторинга и сейчас отмечаются его ограниченные возможности и несистематический характер, часто обусловленные недоступностью подробных данных об источниках загрязнения, химическом и дисперсном составе выбросов. Даже с учетом давней истории экологических наблюдений отмечается отсутствие масштабных комплексных оценок разрушения экосистемы НПР [2], слабая геоэкологическая и геокриологическая изученность района [4], а также противоречивость информации об экологической обстановке на данной территории [44].

\section{Регулирующие документы и контроль. Подходы к расчету и ликвидации накопленного экологического ущерба}

Законодательство в сфере экологии предусматривает три вида экологического контроля: государственный надзор, производственный контроль непосредственно на предприятиях, а также общественный контроль. Одной из основных задач в большинстве регулирующих документов называется расчет и ликвидация накопленного экологического ущерба, то есть последствий хозяйственной деятельности, осуществляемой в прошлом и обусловившей нынешнее загрязнение, которое продолжает наносить вред окружающей среде и является основной экологической проблемой Арктики. Наиболее важным этапом является оценка экологического ущерба: составление карт с пострадавшими участками, оценка их опасности, выявление возможностей регенерации. Последу- ющими задачами по ликвидации накопленного экологического ущерба являются: а) очистка водоемов от затопленных и брошенных объектов и опасных загрязняющих веществ; б) подготовка, вывоз и утилизация бочек; в) вывоз и утилизация транспорта и металлолома; г) вывоз и утилизация радиоизотопных термоэлектрических генераторов (РИТЭГов); д) ликвидация отвалов горно-промышленных комбинатов; е) ликвидация нефтезагрязнений [5].

Государственный надзор в сфере экологии и проблемы в его реализации

На текущий момент разработано и находится в действии несколько законодательных актов и положений, регулирующих оценку экологической обстановки в российской Арктике, подходы к ликвидации накопленного ущерба и стратегию дальнейшего освоения северных территорий.

С 18 сентября 2008 г. действовали утвержденные Президентом Российской Федерации «Основы государственной политики РФ в Арктике на период до 2020 г. и дальнейшую перспективу» № 1969, а с 08 февраля 2013 г. - «Стратегия развития Арктической зоны и обеспечение безопасности на период до 2020 г.», где особое внимание уделялось ликвидации последствий ущерба, нанесенного в предыдущие годы [5, 16]. С 17 февраля 2012 г. действует утвержденный Правительством России проект «Основы государственной политики в области экологического развития Российской Федерации до 2030 года».

С 2019 по 2024 г. в рамках Указа Президента № 204 «О национальных целях и стратегических задачах развития Российской Федерации на период до 2024 года» от 07 мая 2018 г. функционирует национальный проект «Экология», предусматривающий комплекс мероприятий по снижению выбросов загрязняющих веществ в атмосферный воздух в крупных промышленных центрах, включая Норильск. В 2020 г. были изданы «Основы государственной политики РФ в Арктике на период до 2035 года» и «Стратегия развития АЗРФ и обеспечения национальной безопасности на период до 2035 года», также касающиеся вопросов экологии и рационального природопользования в Арктике [61].

При решении задач оценки и ликвидации накопленного экологического ущерба первостепенное значение имеет сбор информации о местоположении объектов, объемах загрязнения, технологии утилизации поллютантов, логистике. Для расчета ущерба, причиненного различным компонентам экосистемы, разработаны соответствующие индивидуальные методики:

- Методика исчисления размера вреда, причиненного водным объектам вследствие нарушения водного законодательства. Утверждена приказом Минприроды РФ от 13 апреля 2009 г. № 87.

- Методика определения размеров ущерба от деградации почв и земель. Утверждена Минприроды России и Роскомземом в июле 1994 г.

- Порядок определения размеров ущерба от загрязнения земель химическими веществами. Утвержден Роскомземом и Минприроды РФ в 1993 г. 
- Об исчислении размера вреда, причиненного лесам вследствие нарушения лесного законодательства. Постановление Правительства РФ от 26 ноября 2007 г. № 806.

- Методика исчисления размера вреда, причиненного водным биологическим ресурсам. Утверждена приказом Федерального агентства по рыболовству от 25 ноября 2011 г. № 1166.

- Методика исчисления размера ущерба от загрязнения подземных вод от 11 февраля 1998 г. № 81.

В каждой методике реализуется декомпозиция экологического ущерба по компонентам окружающей среды (почвы, водные объекты, леса, биологические ресурсы), а ущерб для каждого компонента детализируется по элементам вредного воздействия. Например, в случае деградации почв и земель учитываются такие элементы вредного воздействия, как технологическая и физическая деградация, эрозия, засоление, осолонцевание, заболачивание. При загрязнении земель химическими веществами ущерб определяется количеством загрязняющих веществ, степенью и глубиной загрязнения почв, захламлением земель несанкционированными свалками отходов. Трудности возникают при оценке ущерба, наносимого представителям малочисленных народов арктических территорий, когда устоявшаяся жизнь и промыслы коренных народов оказываются под угрозой из-за биодеградации пресных водоемов, накопления стойких органических загрязнителей и стойких токсичных веществ в традиционной пище, загрязнения мест охотничьих и рыболовных промыслов.

На международном уровне часто применяется «воспроизводственный» подход компенсации ущерба, при котором нарушитель возмещает ущерб в натуральной форме за счет восстановительных работ. Также при наличии могут быть задействованы специализированные природоохранные распределительные фонды целевого назначения [61].

Реализации государственных планов по эффективному контролю экологической ситуации на арктических территориях России, по расчету и ликвидации накопленного экологического ущерба препятствуют несколько ключевых проблем, решение которых является залогом устойчивого развития Арктики и освоения ее ресурсов. Характерной особенностью России в решении вопросов расчета накопленного в Арктике ущерба и его ликвидации является несистемность проводимых мер, а также отставание в решении этой проблемы от других стран с арктическими территориями [11]. К этой проблеме добавляется недостаточное развитие нормативно-правовой базы, а также частое несоблюдение технологических и природоохранных регламентов при проведении работ [4, 17]. К примеру, трудно применимым оказывается международный «воспроизводственный» подход, поскольку отсутствуют четкие требования к содержанию проектов восстановительных работ и не прописан порядок учета затрат, которые понес сам нарушитель во время ликвидации аварий [61]. Ликвидация накопленного экологического вреда осуществляется на ограниченных территориях и не во всех субъектах
России. Координация работ на федеральном и региональном уровнях осуществляется слабо, нет общей программы работ. Нередко отсутствуют законодательные акты, четко фиксирующие процедуру применения методик и самого процесса возмещения вреда, что приводит к неэффективности их использования [61].

Нерешенной остается проблема централизованных подходов, например, ГОСТ накопленного экологического ущерба 2010 г. на материалах юга Сибири, при котором не учитывается специфика арктических территорий, диктующих особенности производственных процессов. На примере «Норникеля» и некоторых других ресурсных и обрабатывающих компаний выявлен ряд существенных отличий, диктуемых спецификой Арктики, от прочих российских и международных корпораций, что в обязательном порядке должно учитываться при разработке теории о закономерностях образования, пространственного поведения и эволюции ресурсных корпораций, в итоге влияющих и на экологическую политику таких компаний [3].

Не учитываются географические или природноклиматические условия и в федеральных законах, peгламентирующих порядок возмещения экологического вреда $[4,17,62]$. Оборотной стороной проблемы является разработка излишне строгих, а потому часто невыполнимых регламентов, требующих применения сверхдорогих технологий очистки и восстановления экосистем. В то же время для предотвращения аварийных ситуаций строгое соблюдение рекомендуемых сроков диагностики и эксплуатации объектов промышленной инфраструктуры согласно ГОСТам представляется вполне оправданным.

В настоящее время регулирование экологической обстановки арктической зоны осуществляется несколькими ведомствами: Минздравом РФ (разработка ПДК и оценка влияния на здоровье населения); Минприроды РФ (оценка влияния на флору и фауну); Минпромторгом РФ (контроль технологических процессов производства), что в целом усложняет ситуацию [17]. Отмечаются противоречия в документах, а также отсутствие в некоторых случаях научной обоснованности и экспериментальной проверки. Закрытость информации сказывается на доминирующем негативном образе окружающей среды российской Арктики как в отечественных, так и в международных публикациях [44]. Парадоксальной является ситуация, при которой концентрация прибыли формируется не на арктических территориях, а вдали от них, так что к решению экологических проблем и поддержке северных территорий должно подключаться государство, которому необходимо переориентировать средства в Арктику из федерального бюджета [3].

\section{Производственный контроль}

За прошедшее десятилетие отмечено совершенствование экологической политики на предприятиях российской Арктики, хотя и с оговоркой, что текущих вложений в природоохранные мероприятия оказывается недостаточно, а инновационные ресурсосбере- 
гающие технологии реализуются не везде и не в полной мере [7]. Потенциал внедрения инноваций и быстрого реагирования на катастрофы оказался в большой степени зависим от типов управления компаниями, где в более ранние периоды их развития предпочтительными оказываются жесткие централизованные подходы, тогда как при превращении в крупные корпорации со множеством филиалов лучшие результаты дает делегирование полномочий в филиалы [3].

В НПР, в отличие от многих корпораций Севера по добыче и обработке полезных ископаемых, компания «Норникель» в области защиты окружающей среды показывает положительную динамику и последовательно увеличивает расходы на охрану окружающей среды [7]. Повышаются системы для очистки выбросов пыли, стабилизируется процесс сжигания топлива, снижается содержание серы в переработке сырья, в целом снижаются объемы отходов (с 2011 по 2018 гг. на 25 \%) и выбросов в атмосферу, чему способствуют новые технологии строительства карьеров и снижение объемов добычи открытым способом $[7,34]$.

В 2004 г. «Норникель» запустил программу, направленную на внедрение интегрированной системы менеджмента качества и экологического менеджмента в главном управлении и производственных подразделениях, отвечающей международным стандартам. Были разработаны методические подходы по экологическому контролю для минимизации отрицательного воздействия на природную среду с установкой автоматизированных датчиков измерения и учета в местах выброса, информация от которых стекается в единый центр управления данными [54].

В 2009 г. в «Норникеле» была завершена программа формирования собственного парка транспортных судов-контейнеровозов. В 2015 г. запущена программа реконфигурации производственных мощностей, предполагающая существенное снижение выбросов серы $[29,63,64]$. В 2016 г. основное производство по переработке никеля и металлов платиновой группы было перемещено из Заполярного филиала на Кольскую горно-металлургическую компанию для приближения производства к рынкам сбыта и, соответственно, для смягчения экологических проблем. В 2018 г. был запущен проект на Талнахской фабрике, предполагающий к 2025 г. на 90 \% снизить выбросы серы в атмосферу [3]. Проблемы экологии и промышленной безопасности призван снизить и проект «Техпрорыв», направленный на переход к «зеленой» экономике с помощью технологий искусственного интеллекта, в том числе с использованием дронов и роботов. Быстро развивается платформенная модель процесса добычи полезных ископаемых, характеризуемая компактностью, обособленностью, новой логистикой и полной цифровизацией всех бизнеспроцессов. Благодаря этому внедряются существенно меньшие по размеру технологии сжатого рабочего пространства, происходит сокращение внутризаводских перемещений и компактное размещение производственных площадок [15].
Экологический контроль остается одной из важнейших правовых мер по обеспечению рационального использования природных ресурсов НПР и защиты окружающей среды от вредного воздействия. Это наглядно подтвердила авария на ТЭЦ-3, где были выявлены нарушения в порядке сроков проведения капитального ремонта резервуара и недостаточная эффективность боновых заграждений, пропускающих многие вредные соединения [40, 65], хотя по данным спутниковых снимков и отмечается оперативность служб по ликвидации аварии [41]. Таким образом, вопросы о недостаточной эффективности технического и экологического контроля продолжают быть актуальными, и даже с учетом увеличения экологических издержек «Норникеля» отмечается необходимость усиления контроля [44].

\section{Общественный контроль}

Модель общественного экологического контроля на арктических территориях России набрала популярность в последнее десятилетие. Эта концепция, от которой ожидается высокий положительный эффект, предполагает предоставление общественности данных мониторинга и возможности ее участия в принятии значимых решений при проведении экологической экспертизы [54]. Таким образом, модель позволяет гражданам и общественным объединениям реализовать право на получение своевременной, полной и достоверной информации о состоянии окружающей среды в местах своего проживания и предпринимаемых мерах по охране окружающей среды [54, 55, 66].

Цели общественного контроля в российской Арктике включают объединение усилий различных групп населения северных территорий, руководства предприятий и государственных надзорных органов в решении проблем охраны окружающей среды, систематическое отслеживание экологических тенденций на территории, создание условий для межведомственного взаимодействия, совершенствование государственной политики в области экологии и, как следствие, содействие экологическому воспитанию населения.

\section{Рекомендации}

Поскольку самостоятельно на переработку отходов природе потребуются десятки, если не сотни, лет, оперативное решение обозначенных выше задач представляется крайне актуальным. Их решение видится в разработке особых режимов природопользования и охраны окружающей природной среды - с учетом особенностей арктических территорий, совершенствования государственного регулирования относительно загрязнения арктических экосистем, постоянного мониторинга загрязнения, рекультивации ландшафтов, утилизации токсичных отходов и обеспечения химической безопасности, в особенности в местах компактного проживания людей [7, 67, 68]. Предлагается в отчетных документах указывать научно обоснованные и конкретные проведенные мероприятия по повышению эффективности природоохранной деятельности, а также усилить связь пред- 
приятий с научными организациями для совместной разработки и реализации инновационных технологий, направленных на снижение пагубного воздействия на природу Арктики [7, 61, 67].

При крупных экологических катастрофах полезным могло бы оказаться привлечение международных партнеров, как для точной оценки ущерба, так и для разработки возможных совместных действий по ликвидации последствий аварии, чему в настоящий момент противоречит режим регламентированного въезда в Норильск иностранцев и необходимость специальных согласований. Некоторым исключением может служить Международная Хартия в целях мониторинга разлива топлива на ТЭЦ-3 в Норильске в 2020 г. [69].

Наиболее перспективным в решении экологических проблем Арктики и ликвидации накопленного ущерба представляется развитие государственночастного партнерства [70], в том числе с привлечением общественности. Это продиктовано и самой спецификой расположения корпораций в малонаселенных и удаленных районах, где их функции не имеют конкурентов, а потому взаимодействие корпораций с государством и населением становится намного более полным и многоаспектным в сравнении с корпорациями, расположенными на освоенных территориях [3]. В этой же связи ждет решения проблема приобретения прав собственности на отходы и земельные участки, на которых они расположены. С одной стороны, это актуально, поскольку бывший собственник не сможет заявить на них права, с другой - предполагается, что бывший собственник будет обязан возместить новому владельцу земельного участка причиненный брошенными отходами вред, а также расходы на перемещение отходов в места их сбора [69].

\section{СПИСОК ЛИТЕРАТУРЫ}

1. Бурцева Е.И., Петрова А.Н. Экологические проблемы северных территорий Якутии в условиях промышленного освоения и глобального потепления // Успехи современного естествознания. - 2017. - № 5. - С. 83-88.

2. Ecological and conceptual consequences of Arctic pollution/ A.V. Kirdyanov, P.J. Krusic, V.V. Shishov, E.A. Vaganov, A.I. Fertikov, V.S. Myglan, V.V. Barinov, J. Browse, J. Esper, V.A. Ilyin, A.A. Knorre, M.A. Korets, V.V. Kukarskikh, D.A. Mashukov, A.A. Onuchin, A. Piermattei, A.V. Pimenov, A.S. Prokushkin, V.A. Ryzhkova, A.S. Shishikin, K.T. Smith, A.V. Taynik, M. Wild, E. Zorita, U. Büntgen // Ecology Letters. 2020. - V. 23. - № 12. - P. 1827-1837.

3. Пилясов А.Н., Богодухов А.О. Арктическая корпорация: подступы к формированию новой теории (Часть 1) // ЭКО. 2021. - № 1. - С. 40-66.

4. Лаухин С.А. О некоторых проблемах накопленного экологического ущерба от недропользования в российской Арктике (на примере Востока России) // Геоэкология. Инженерная геология, гидрогеология, геокриология. - 2020. - № 1. - С. 76-81.

5. Соколов Ю.И. Акртика: к проблеме накопленного экологического ущерба // Арктика: экология и экономика. - 2013. № 2. - C. 18-27.

6. Летучий Ю.А. Оценивание экологического ущерба от деятельности Вооруженных сил в Арктическом регионе // Труды военно-космической академии имени А.Ф. Можайского. 2015. - № 649. - C. 175-180.

7. Цукерман В.А., Иванов С.В. Экологическая политика ресурсных корпораций при промышленном освоении месторождений минерального сырья арктической зоны Российской Федерации // Горный информационно-аналитический бюллетень. 2020. - № 10. - C. 56-66

\section{Заключение}

Арктика благодаря стратегическим запасам ресурсов входит в сферу особых геополитических и национальных интересов Российской Федерации. Особенность арктической природы заключается в ее чрезвычайной чувствительности как к естественным, так и к антропогенным воздействиям, а также в низкой способности экосистем к восстановлению и в их неустойчивости. Наиболее острые экологические задачи текущего дня включают рекультивацию нарушенных земель, ликвидацию ущерба за предыдущие периоды и последствий от потепления климата.

Главными источниками загрязнения на текущий момент являются деятельность добывающей и обрабатывающей промышленности, аварийные ситуации на производстве, объекты обеспечения функционирования Вооруженных Сил России, последствия ядерных испытаний и деятельности АЭС, организация перевозки грузов и людей, заброшенные объекты хозяйственной деятельности, токсиканты, перенесенные воздушными потоками и поверхностным стоком в Арктику из средних широт.

В качестве рекомендации по решению существующих экологических задач на арктических территориях предлагается разработка режимов природопользования с учетом локальных особенностей, совершенствование государственного регулирования и совершенствование системы мониторинга окружающей среды. Эти меры предполагается осуществлять в рамках государственно-частного партнерства с активным привлечением общественности.

Исследование выполнено при финансовой поддержке программы ФНИ (проект № 0266-2019-0008).

8. Динамика усыхания лиственницы сибирской в зоне влияния техногенных эмиссий предприятий Норильского промышленного района / А.В. Кирдянов, В.С. Мыглан, А.В. Пименов, А.А. Кнорре, А.К. Экарт, Е.А. Ваганов // Сибирский экологический журнал. - 2014. - № 6. - С. 945-952.

9. Оценка состояния микробных комплексов почв лесотундровой зоны в условиях аэротехногенного загрязнения / А.В. Богородская, Т.В. Пономарева, О.А. Шапченкова, А.С. Шишикин // Почвоведение. - 2012. - № 5. - С. 582-593.

10. Ведрова Э.Ф., Мухортова Л.В. Биогеохимическая оценка лесных экосистем в зоне влияния Норильского промышленного комплекса // Сибирский экологический журнал. - 2014. № 6. - C. 933-944.

11. Оценка значения стойких токсичных веществ в накопленном экологическом ущербе для Арктики / М.В. Чащин, Е. Барнес, Р.С. Даер, Н.В. Захарова, И.Л. Ручина, Е.В. Зибарев, А.В. Кузьмин, К.В. Корбукова, Л.И. Абрютина // Экология человека. - 2009. - № 2. - С. 8-12.

12. Геохимические закономерности распространения элементов в водах озер арктических регионов / Т.И. Моисеенко, М.И. Дину, Н.А. Гашкина, Т.А. Кремлева, В.Ю. Хорошавин // Геохимия. - 2020. - Т. 65. - № 6. - С. 521-532.

13. Сазонов А.Д., Комаров Р.С., Передера О.С. Разлив нефтепродуктов в Норильске 29 мая 2020 года: предполагаемые причины и возможные экологические последствия // Экология. Экономика. Информатика. Серия: Системный анализ и моделирование экономических и экологических систем. $-2020 .-$ T. 1. № 5. - C. 173-177.

14. Терещенко С.В., Марчевская В.В., Павлишина Д.Н. Пути снижения негативного воздействия горного производства на окружающую природную среду // Вестник Кольского научного центра РАН. - 2016. - № 4. - С. 62-66. 
15. Shchelkunova R.P. The effect of industry and transport on reindeer pastures: the example of Taymyr // Polar Geography and Geology. - 1993. - V. 17. - № 4. - P. 251-258.

16. Исследование объектов накопленного экологического ущерба на острове Вилькицкого (Карское море)/ Р.А. Колесников, В.М. Макеев, Е.Н. Романова, В.И. Стурман, К.А. Журкина // Инженерные изыскания. - 2018. - С. 12. - № 5-6. - С. 32-41.

17. Актуальные проблемы предотвращения, ликвидации разливов нефти в Арктике и методы оценки экологического ущерба прибрежным территориям / В.И. Павленко, Ж. Муангу, В.Б. Коробов, А.С. Лохов // Арктика: экология и экономика. 2015. - № 3. - C. 4-11.

18. Characterization of viable bacteria from siberian permafrost by 16S rDNA sequencing / T. Shi, R.H. Reeves, D.A. Gilichinsky, E.I. Friedmann // Microbial Ecology. - 1997. - V. 33. - № 3. P. 169-179.

19. Isolation and degradation potential of a cold-adapted oil/PAHdegrading marine bacterial consortium from Kongsfjorden (Arctic region)/ F. Crisafi, L. Giuliano, M.M. Yakimov, M. Azzaro, R. Denaro // Rendiconti Lincei-Scienze Fisiche E Naturali. 2016. - V. 27. - P. 261-270.

20. Микроорганизмы в ликвидации последствий нефтяного загрязнения (обзор)/ Т.Ю. Коршунова, С.П. Четвериков, М.Д. Бакаева, Е.В. Кузина, Г.Ф. Рафикова, Д.В. Четверикова, О.Н. Логинов // Прикладная биохимия и микробиология. 2019. - T. 55. - № 4. - C. 338-349.

21. Соловьянов А.А. Экологические проблемы Арктической зоны Российской Федерации: состояние и пути решения // Охрана атмосферного воздуха. Атмосфера. - 2011. - № 2. - С. 21-30.

22. Влияние затонувших судов на экологическую безопасность прибрежных акваторий и береговых зон России / Н.А. Вальдман, С.В. Викторов, В.Н. Илюхин, Л.Л. Озерова // Труды Крыловского государственного научного центра. - 2019. № 4. - C. 231-244.

23. Ложкина О.В., Онищенко И.А. Анализ опасного загрязнения атмосферного воздуха крупных городов арктической зоны отработавшими газами транспортных средств// Проблемы управления рисками в техносфере. - 2020. - № 3. - С. 20-26.

24. Lake drainage in permafrost regions produces variable plant communities of high biomass and productivity / S. Loiko, N. Klimova, D. Kuzmina, O. Pokrovsky // Plants. - 2020. - V. 9. № 7. - P. $1-42$

25. Impact of permafrost thaw and climate warming on riverine export fluxes of carbon, nutrients and metals in Western Siberia/ O.S. Pokrovsky, R.M. Manasypov, S.G. Kopysov, I.V. Krickov, L.S. Shirokova, S.V. Loiko, A.G. Lim, L.G. Kolesnichenko, S.N. Vorobyev, S.N. Kirpotin // Water (Switzerland). - 2020. V. 12. - № 6. - P. 1-21.

26. Проблемы контроля фильтрации вод через гидротехнические сооружения в условиях вечной мерзлоты / Н.В. Юркевич, Н.В. Юркевич, В.Н. Гуреев, Н.А. Мазов // Известия Томского политехнического университета. Инжиниринг георесурсов. 2020. - T. 331. - № 4. - C. 126-138.

27. Пилясов А.Н., Богодухов А.О. Арктическая корпорация: подступы к формированию новой теории (Часть 2) // ЭКО. 2021. - № 2. - C. 62-84.

28. Bazhenov O., Oykher A. Strategic analysis of environmental and economic potential of Norilsk metallurgical cluster / International Conference on Efficient Production and Processing (ICEPP-2020). - Prague, Czech Republic, February 27-28, 2020). E3S Web of Conferences. -2020 . - V. 161. - P. 1-6.

29. Леонтьев Л.И., Тарасов А.В. Экологические проблемы «Норильского никеля» и возможные пути их решения // Экология и промышленность России. - 2017. - Т. 21. - № 2. - С. 15-19.

30. Nemirovskaya I.A., Shevchenko V.P. Organic compounds and suspended particulate matter in snow of high latitude areas (Arctic and Antarctic) // Atmosphere. - 2020. - V. 11. - № 9. - P. 1-23.

31. Численное исследование процессов переноса и трансформации газовых и аэрозольных примесей в шлейфе выбросов Норильского промышленного района / В.Ф. Рапута, Д.В. Симоненков, Б.Д. Белан, Т.В. Ярославцева // Оптика атмосферы и океана. - 2018. - Т. 31. - № 6. - С. 438-442.

32. Загрязнение снежного покрова в зоне воздействия предприятий Норильского промышленного района / А.А. Онучин, Т.А. Буренина, О.Н. Зубарева, О.В. Трефилова, И.В.
Данилова // Сибирский экологический журнал. - 2014. № 6. - C. 1025-1037.

33. Телятников М.Ю., Пристяжнюк С.А. Антропогенное влияние предприятий Норильского промышленного района на растительный покров тундры и лесотундры // Сибирский экологический журнал. - 2014. - № 6. - С. 903-922.

34. Long-term changes of heavy metal and sulphur concentrations in ecosystems of the Taymyr Peninsula (Russian Federation) North of the Norilsk Industrial Complex / A.V. Zhulidov, R.D. Robarts, D.F. Pavlov, J. Kämäri, T.Y. Gurtovaya, J.J. Meriläinen, I.N. Pospelov // Environmental Monitoring and Assessment.2011. - V. 181. - № 1-4. - P. 539-553.

35. Виноградова А.А., Максименков Л.О., Погарский Ф.А. Изменения атмосферной циркуляции и загрязнения окружающей среды в Сибири от промышленных районов Норильска и Урала в начале XXI в. // Оптика атмосферы и океана. - 2009. T. 22. - № 6. - C. 527-234.

36. Concentrations of $\mathrm{Cd}, \mathrm{Pb}, \mathrm{Zn}$ and $\mathrm{Cu}$ in pristine wetlands of the Russian Arctic/ A.V. Zhulidov, J.V. Headley, R.D. Robarts, A.M. Nikanorov, A.A. Ischenko, M.A. Champ // Marine Pollution Bulletin. - 1997. - V. 35. - № 7-12. - P. 242-251.

37. Concentrations of $\mathrm{Cd}, \mathrm{Pb}, \mathrm{Zn}$ and $\mathrm{Cu}$ in contaminated wetlands of the Russian Arctic / A.V. Zhulidov, J.V. Headley, R.D. Robarts, A.M. Nikanorov, A.A. Ischenko, M.A. Champ // Marine Pollution Bulletin. - 1997. - V. 35. - № 7. - P. 252-259.

38. Гурский Ю.Н. Выявление и оценка уровня антропогенных загрязнений на основе геохимического изучения иловых вод морских и пресноводных отложений // Вестник Московского университета. Серия 4. Геология. - 2017. - № 5. - С. 49-58.

39. Захаров А.И., Захарова Л.Н., Митник Л.М. Мониторинг стабильности топливных резервуаров Норильской ТЭЦ-3 методами радарной интерферометрии // Современные проблемы дистанционного зондирования Земли из космоса. - 2020. T. 17. - № 5. - C. 281-285.

40. Якуцени С.П., Соловьев И.А. Расчет ущерба окружающей среде в результате аварии на складе ГСМ в Норильске // Географическая среда и живые системы. - 2020. - № 4. - С. 48-56.

41. Наблюдение загрязнений реки Амбарной, возникших в результате аварии на ТЭЦ-3 города Норильска 29 мая 2020 г. I К.А. Трошко, П.В. Денисов, О.Ю. Лаврова, Е.А. Лупян, А.А. Медведев // Современные проблемы дистанционного зондирования Земли из космоса. - 2020. - Т. 17. - № 3.C. $267-274$

42. Леженин А.А., Рапута В.Ф., Ярославцева Т.В. Численный анализ атмосферной циркуляции и распространения загрязняющих примесей в окрестностях Норильского промышленного района // Оптика атмосферы и океана. - 2016. - Т. 29. № 6. - C. 467-471.

43. Zaslavskaya M.B., Erina O.N., Efimova L.E. Comparing the efficiency of river water quality parameterization by different methods under a significant human-induced impact // Geography and Natural Resources. - 2019. - V. 40. - № 2. - P. 122-128.

44. Носова О.В., Галишевская В.В., Кармановская Н.В. Мониторинг вод открытых водоемов Норильского промышленного района // Культура. Наука. Производство. - 2020. - № 5. C. $80-85$.

45. Преимущества и недостатки нефтяных сорбентов для ликвидации разливов на акватории в условиях низких температур / Е.А. Мазлова, И.А. Мерициди, Я.Ю. Блиновская, К.К. Размахнин, О.А. Куликова // Защита окружающей среды в нефтегазовом комплексе. - 2020. - № 6. - С. 55-60.

46. Некоторые особенности распределения тяжелых металлов в поверхностном слое донных осадков Карского моря / В.Ю. Русаков, Т.Г. Кузьмина, М.А. Левитан, Е.С. Торопченова, А.В. Жилкина // Геохимия. - 2017. - № 12. - С. 1088-1099.

47. Ji X., Abakumov E., Xie X. Atmosphere-ocean exchange of heavy metals and polycyclic aromatic hydrocarbons in the Russian Arctic Ocean // Atmospheric Chemistry and Physics. - 2019. - V. 19. № 22. - P. 13789-13807.

48. Виноградова А.А., Котова Е.И. Загрязнение северных морей России тяжелыми металлами: поток из атмосферы и речной сток // Геофизические процессы и биосфера. - 2019. - Т. 18. № 1. - C. 22-32.

49. Agbalyan E., Krasnenko A., Shinkaruk E. Concentration of heavy metals and metalloids in the bottom sediments of the Vilkitsky 
Island's lakes (the Kara Sea) // Actual Problems of Ecology and Environmental Management: Cooperation for Sustainable Development and Environmental Safety (APEEM 2020). Moscow, Russia, April 23-24, 2020. E3S Web of Conferences. 2020. - V. 169. - P. 1-6.

50. Эколого-функциональная оценка состояния почв в зоне аэротехногенного воздействия Норильского промышленного комплекса / Т.В. Пономарева, О.В. Трефилова, А.В. Богородская, О.А. Шапченкова // Сибирский экологический журнал. 2014. - № 6. - C. 987-996.

51. Загрязнение почв выбросами предприятий цветной металлургии / Ю.Н. Водяницкий, И.О. Плеханова, Е.В. Прокопович, А.Т. Савичев // Почвоведение. - 2011. - № 2. - С. 240-249.

52. Ефремова Т.Т., Ефремов С.П. Эколого-геохимическая оценка уровней загрязнения тяжелыми металлами и серой бугристых торфяников юга Таймыра // Сибирский экологический журнал. - 2014. - № 6. - 965-974.

53. Kharuk V.I., Nilsson S., Samarskaia E. Anthropogenic and technogenic stress factors to forests in Siberia // IIASA Working Paper WP-96-104. - Laxenburg, Austria, 1996. - 104 p.

54. Automated systems of ecological control in Norilsk/ N.V. Karmanovskaya, A.T. Smirnova, V.I. Litovchenko, S.G. Efa / $2^{\text {nd }}$ International Scientific Conference on Advanced Technologies in Aerospace, Mechanical and Automation Engineering (MIST Aerospace 2019). IOP Conference Series: Materials Science and Engineering. - Krasnoyarsk, 18-21 November, 2021. - V. 734. P. $1-4$.

55. Кармановская Н.В., Базелянская Т.П. Исследование экологического состояния водных объектов и почв на промышленных арктических территориях // Культура. Наука. Производство. 2020. - № 6. - C. 74-78.

56. Forest disturbance assessment using satellite data of moderate and low resolution/ M.A. Korets, V.A. Ryzhkova, I.V. Danilova, A.I. Sukhinin, S.A. Bartalev // Environmental Change in Siberia. Advances in Global Change Research. - Dordrecht: Springer, 2010. - P. 3-19.

57. Корец М.А., Рыжкова В.А., Данилова И.В. Использование ГИС для оценки состояния наземных экосистем Норильского промышленного района // Сибирский экологический журнал. - 2014. - № 6. - 887-902.

58. IASI observations of sulfur dioxide $\left(\mathrm{SO}_{2}\right)$ in the boundary layer of Norilsk / S. Bauduin, L. Clarisse, C. Clerbaux, D. Hurtmans, P.-F. Coheur // Journal of Geophysical Research: Atmospheres. 2014. - V. 119. - № 7. - P. 253-263.

59. Environmental risk zones mapping using satellite monitoring data A. Zotin, D. Zuev, V. Kashkin, M. Kurako, K. Simonov // Procedia Computer Science. - 2018. - V. 126. - P. 1597-1605.
60. Анализ содержания $\mathrm{CO}_{2}$ вблизи российских городов по спутниковым измерениям ОСО-2 / А.А. Никитенко, Ю.М. Тимофеев, И.А. Березин, Я.А. Виролайнен, А.В. Поляков // Оптика атмосферы и океана. - 2020. - Т. 33. - № 7. - С. 538-543

61. Шевчук А.В. Эколого-экономические аспекты развития Арктики // Научные труды Вольного экономического общества России. - 2020. - Т. 226. - № 6. - С. 146-162.

62. Рудакова Л.В., Рудаков Р.Б. Обоснование особого подхода к правовому регулированию возмещения экономического ущерба от экологических нарушений в Арктических районах // Экологическая безопасность промышленных регионов: III Уральский международный экологический конгресс. Екатеринбург, 25-31 мая 2015. - Екатеринбург: СОО МАНЭБ, ИЭ УрО РАН, УГГУ, 2015. - С. 252-256.

63. Леонтьев Л.И., Тарасов А.В. Экологические проблемы «Норильского никеля» и возможные пути их решения. Ч. 3. Сера и eе применение // Экология и промышленность России. 2017. - Т. 21. - № 5. - С. 11-15.

64. Леонтьев Л.И., Тарасов А.В. Экологические проблемы «Норильского никеля» и возможные пути их решения. Ч. 2. Применение и утилизация диоксида серы // Экология и промышленность России. - 2017. - Т. 21. - № 4. - С. 20-25.

65. Коптев Д.П. Норильский разлив: уроки и последствия // Бурение и нефть. -2020 . - № 7-8. - С. 3-9.

66. Кармановская Н.В. Производственный и общественный экологический контроль в Норильске // Экология урбанизированных территорий. - 2020. - № 2. - С. 94-99.

67. Tsukerman V.A., Ivanov S.V. Management of the industrial waste when exploiting mineral resources of the Arctic // $17^{\text {th }}$ International Symposium on Solid Oxide Fuel Cells (SOFC-XVII) IOP Conference Series: Earth and Environmental Science. 18-23 July, 2020. - V. 459 - P. 1-5.

68. Экологические проблемы Арктики. - 2021. URL: https:// arctic.narfu.ru/spisok-literatury/ekologiya/ekologicheskieproblemy-arktiki (дата обращения: 22.05.2021).

69. Activation-655 - Oil spill in Russia. - 2021. URL: https:// cgt.disasterscharter.org/en/655 (дата обращения: 22.05.2021).

70. Харитонова Г.Н. Финансовые механизмы и организационные модели ликвидации накопленного экологического ущерба в районах Крайнего Севера // Проблемы рационального использования природного и техногенного сырья Баренц-региона в технологии строительных и технических материалов: 5-я Всероссийская научная конференция с международным участием. - Апатиты, 12-15 ноября 2013. - С. 190-195.

Поступила 25.05.2021 2.

\section{Информация об авторах}

Юркевич Н.В., кандидат технических наук, старший научный сотрудник лаборатории эколого-экономического моделирования техногенных систем, Институт нефтегазовой геологии и геофизики им. А.А. Трофимука СО РАН. Ельцов И.Н., доктор технических наук, профессор, директор Института нефтегазовой геологии и геофизики им. А.А. Трофимука СО РАН.

Гуреев В.Н., кандидат педагогических наук, старший научный сотрудник информационно-аналитического центра, Институт нефтегазовой геологии и геофизики им. А.А. Трофимука СО РАН; доцент, Новосибирский государственный технический университет.

Мазов Н.А., кандидат технических наук, заведующий информационно-аналитическим центром, Институт нефтегазовой геологии и геофизики им. А.А. Трофимука СО РАН.

Юркевич Н.В., кандидат геолого-минералогических наук, заведующая лабораторией эколого-экономического моделирования техногенных систем, Институт нефтегазовой геологии и геофизики им. А.А. Трофимука СО РАН.

Edeлев A.B., кандидат геолого-минералогических наук, старший научный сотрудник лаборатории экологоэкономического моделирования техногенных систем, Институт нефтегазовой геологии и геофизики им. А.А. Трофимука СО РАН. 
UDC 574(1-925.121)

\title{
TECHNOGENIC EFFECT ON THE ENVIRONMENT IN THE RUSSIAN ARCTIC BY THE EXAMPLE OF THE NORILSK INDUSTRIAL AREA
}

\author{
Nikolay V. Yurkevich ${ }^{1}$, \\ YurkevichNV2@ipgg.sbras.ru \\ Igor N. Eltsov1, \\ YeltsovIN@ipgg.sbras.ru \\ Vadim N. Gureev1,2, \\ GureyevVN@ipgg.sbras.ru \\ Nikolay A. Mazov', \\ MazovNA@ipgg.sbras.ru \\ Nataliya V. Yurkevich ${ }^{1}$, \\ YurkevichNV@ipgg.sbras.ru \\ Aleksey V. Edelev'1, \\ EdelevAV@ipgg.sbras.ru \\ 1 Trofimuk Institute of Petroleum Geology and Geophysics, SB RAS, \\ 3, Koptyug avenue, Novosibirsk, 630090, Russia. \\ 2 Novosibirsk State Technical University, \\ 136, Nemirovich-Danchenko street, Novosibirsk, 630087, Russia.
}

The relevance of the study is caused by the increased necessity to solve ecological issues in Russian Arctic regions considering their importance for the development of the country. The task complexity lies both in the presence of cumulative environmental damage and the topicality to elaborate sustainable approaches to natural resource development in the near future.

The main aim is to analyze the condition of the ecosystem and its separate components in the Norilsk industrial area as one of the significant resource territories in the Russian Arctic. Special attention is paid to techniques of monitoring the environment and official documents regulating ecology that require the elimination of acute contradictions and legislative vacuum.

Methods of the research include analyses of research papers published in Russian and foreign sources in the last decade on environmental challenges in the Russian Arctic and especially in the Norilsk industrial area. Various bibliographic systems including the Russian Science Citation Index, Scopus, and "Environment protection» abstract service by VINITI were used.

Results. Unique characteristics of Arctic regions were revealed that require both non-traditional technological concepts when conducting an industrial activity, and special approaches when regulating and controlling ecological state. The example of the Norilsk industrial area was used to demonstrate improvements in ecological aspects of industrial activity of mining and smelting enterprise even despite the incident with a fuel spill in 2020. However, the attempted measures are still insufficient to regard the current ecological situation as satisfactory. The problems of neutralization of cumulative environmental damage have awaited solutions. The efficiency of planned measures for improvement of the state of the environment essentially depends on changes in legal acts poorly considering specific features of Arctic territories, as well as on closer collaboration of industrial enterprises both with the scientific community and local residents.

\section{Key words:}

Norilsk industrial area, Arctic, ecology, cumulative environmental damage, monitoring.

The research was financially supported by the Fundamental Research program (project no. 0266-2019-0008).

\section{REFERENCES}

1. Burtseva E.I., Petrova A.N. Environmental problems of the Northern Yakutia in the industrial development and global warming. Uspekhi sovremennogo estestvoznaniya, 2017, no. 5, pp. 83-88. In Rus.

2. Kirdyanov A.V., Krusic P.J., Shishov V.V., Vaganov E.A., Fertikov A.I., Myglan V.S., Barinov V.V., Browse J., Esper J., Ilyin V.A., Knorre A.A., Korets M.A., Kukarskikh V.V., Mashukov D.A., Onuchin A.A., Piermattei A., Pimenov A.V., Prokushkin A.S., Ryzhkova V.A., Shishikin A.S., Smith K.T., Taynik A.V., Wild M., Zorita E., Büntgen U. Ecological and conceptual consequences of Arctic pollution. Ecology Letters, 2020, vol. 23, no. 12, pp. 1827-1837.

3. Pilyasov A.N., Bogodukhov A.O. Arctic corporation: approaches to a new theory (P. 1). EKO, 2021, no. 1, pp. 40-66. In Rus.
4. Laukhin S.A. About some problems in the accumulated ecological damage due to the extraction of raw materials in the Russian Arctics (by the example of the Russian East). Geoekologiya. Inzhenernaya geologiya, gidrogeologiya, geokriologiya, 2020, no. 1, pp. 76-81. In Rus.

5. Sokolov Yu.I. Akrtika: $\mathrm{k}$ probleme nakoplennogo ekologicheskogo ushcherba [Arctic: problem of the accumulated environmental damage]. Arktika: ekologiya i ekonomika, 2013, no. 2, pp. 18-27.

6. Letuchiy Yu.A. Otsenivanie ekologicheskogo ushcherba ot deyatelnosti Vooruzhennykh sil $\mathrm{v}$ Arkticheskom regione [Evaluation of ecological damage from admed forces activity in the Arctic region]. Trudy voenno-kosmicheskoy akademii imeni A.F. Mozhayskogo, 2015, no. 649, pp. 175-180.

7. Tsukerman V.A., Ivanov S.V. Environmental policy of resource corporations in commercial mineral production in the Arctic Zone 
of Russia. Gorny informatsionno-analiticheskiy byulleten, 2020, no. 10, pp. 56-66. In Rus.

8. Kirdyanov A.V., Myglan V.S., Pimenov A.V., Knorre A.A., Ekart A.K., Vaganov E.A. Die-off dynamics of Siberian larch under the impact of pollutants emitted by Norilsk enterprises. Contemporary Problems of Ecology, 2014, vol. 7, no. 6, pp. 679-684

9. Bogorodskaya A.V., Ponomareva T.V., Shapchenkova O.A., Shishikin A.S. Assessment of the state of soil microbial cenoses in the forest-tundra zone under conditions of airborne industrial pollution. Eurasian Soil Science, 2012, vol. 45, no. 5, pp. 521-531

10. Vedrova E.F., Mukhortova L.V. Biogeochemical evaluation of forest ecosystems in the area affected by Norilsk industrial complex. Contemporary Problems of Ecology, 2014, vol. 7, no. 6, pp. 669-678.

11. Chashchin M.V., Barnes E., Daer R.S., Zakharova N.V., Ruchina I.L., Zibarev E.V., Kuz'min A.V., Korbukova K.V., Abryutina L.I. Assessment of resistant toxic substances importance in accumulated environmental damage for Arctic region. Ekologiya cheloveka, 2009, no. 2, pp. 8-12. In Rus.

12. Moiseenko T.I., Dinu M.I., Gashkina N.A., Kremleva T.A., Khoroshavin V.Y. Geochemical features of elements distributions in the lake waters of the Arctic region. Geochemistry International, 2020, vol. 58, no. 6, pp. 613-623.

13. Sazonov A.D., Komarov R.S., Peredera O.S. Oil product spill in Norilsk May 29, 2020: alleged reasons and possible environmental impact. Ekologiya. Ekonomika. Informatika. Seriya: Sistemnyy analiz i modelirovanie ekonomicheskikh i ekologicheskikh sistem, 2020, vol. 1, no. 5, pp. 173-177. In Rus.

14. Tereshchenko S.V., Marchevskaya V.V., Pavlishina D.N. Ways to reduce negative environmental impact of mining industry. Vestnik Kolskogo nauchnogo tsentra RAN, 2016, no. 4, pp. 62-66. In Rus.

15. Shchelkunova R.P. The effect of industry and transport on reindeer pastures: the example of Taymyr. Polar Geography and Geology, 1993, vol. 17, no. 4, pp. 251-258.

16. Kolesnikov R.A., Makeev V.M., Romanova E.N., Sturman V.I., Zhurkina K.A. The investigation of the objects of the past environmental damage on the Vilkitsky Island (Kara sea) Inzhenernye izyskaniya, 2018, pp. 12, no. 5-6, pp. 32-41. In Rus.

17. Pavlenko V.I. Muangu Zh., Korobov V.B., Lokhov A.S Aktualnye problemy predotvrashcheniya, likvidatsii razlivov nefti v Arktike i metody otsenki ekologicheskogo ushcherba pribrezhnym territoriyam [Actual problems of the prevention and elimination of oil spills in Arctic and methods of evaluation of ecological damage in coastal territories]. Arktika: ekologiya ekonomika, 2015, no. 3, pp. 4-11.

18. Shi T., Reeves R.H., Gilichinsky D.A., Friedmann E.I. Characterization of Viable Bacteria from Siberian Permafrost by 16S rDNA Sequencing. Microbial Ecology, 1997, vol. 33, no. 3, pp. $169-179$.

19. Crisafi F., Giuliano L., Yakimov M.M., Azzaro M., Denaro R. Isolation and degradation potential of a cold-adapted oil/PAHdegrading marine bacterial consortium from Kongsfjorden (Arctic region). Rendiconti Lincei-Scienze Fisiche E Naturali, 2016, vol. 27, pp. 261-270.

20. Korshunova T.Y., Chetverikov S.P., Bakaeva M.D., Kuzina E.V., Rafikova G.F., Chetverikova D.V., Loginov O.N. Microorganisms in the Elimination of Oil Pollution Consequences (Review). Applied Biochemistry and Microbiology, 2019, vol. 55, no. 4, pp. 344-354.

21. Solovyanov A.A. Ekologicheskie problemy Arkticheskoy zony Rossiyskoy Federatsii: sostoyanie i puti resheniya [Ecological problems in Arctic zones of Russian Federation: current condition and ways of solution]. Okhrana atmosfernogo vozdukha. Atmosfera, 2011, no. 2, pp. 21-30.

22. Val'dman N.A., Viktorov S.V., Ilyukhin V.N., Ozerova L.L. Environmental impact of sunken ships upon Russian coastal waters and shorelands. Trudy Krylovskogo gosudarstvennogo nauchnogo tsentra, 2019, no. 4, pp. 231-244. In Rus.

23. Lozhkina O.V., Onishchenko I.A. Analiz opasnogo zagryazneniya atmosfernogo vozdukha krupnykh gorodov arkticheskoy zony otrabotavshimi gazami transportnykh sredstv [Analysis of dangerous air pollution of big cities in the arctic zone by vehicle exhaust emissions]. Problemy upravleniya riskami v tekhnosfere, 2020, no. 3, pp. 20-26.
24. Loiko S., Klimova N., Kuzmina D., Pokrovsky O. Lake drainage in permafrost regions produces variable plant communities of high biomass and productivity. Plants, 2020, vol. 9, no. 7, pp. 1-42.

25. Pokrovsky O.S., Manasypov R.M., Kopysov S.G., Krickov I.V., Shirokova L.S., Loiko S.V., Lim A.G., Kolesnichenko L.G., Vorobyev S.N., Kirpotin S.N. Impact of permafrost thaw and climate warming on riverine export fluxes of carbon, nutrients and metals in Western Siberia. Water (Switzerland), 2020, vol. 12, no. 6, pp. 1-21.

26. Yurkevich N.V., Yurkevich N.V., Gureev V.N., Mazov N.A. Problems of controlling water filtration in hydraulic structures in permafrost regions. Bulletin of the Tomsk Polytechnic University. Geo Assets Engineering, 2020, vol. 331, no. 4, pp. 126-138. In Rus.

27. Pilyasov A.N., Bogodukhov A.O. Arctic corporation: approaches to a new theory (P. 2). EKO, 2021, no. 2, pp. 62-84. In Rus.

28. Bazhenov O., Oykher A. Strategic analysis of environmental and economic potential of Norilsk metallurgical cluster. International Conference on Efficient Production and Processing (ICEPP-2020). E3S Web of Conferences. Prague, Czech Republic, February 27-28, 2020. Vol. 161, pp. 1-6.

29. Leont'ev L.I., Tarasov A.V. Environmental challenges of «Norilsk Nickel» and their possible solutions. Ekologiya i promyshlennost Rossii, 2017, vol. 21, no. 2, pp. 15-19. In Rus.

30. Nemirovskaya I.A., Shevchenko V.P. Organic compounds and suspended particulate matter in snow of high latitude areas (Arctic and Antarctic). Atmosphere, 2020, vol. 11, no. 9, pp. 1-23.

31. Raputa V.F., Simonenkov D.V., Belan B.D., Yaroslavtseva T.V. Numerical study of gas and aerosol impurity transfer and transformation processes in the plume of the Norilsk industrial region. Atmospheric and Oceanic Optics, 2018, vol. 31, no. 5, pp. 466-470.

32. Onuchin A.A., Burenina T.A., Zubareva O.N., Trefilova O.V., Danilova I.V. Pollution of snow cover in the impact zone of enterprises in Norilsk Industrial Area. Contemporary Problems of Ecology, 2014, vol. 7, no. 6, pp. 714-722.

33. Telyatnikov M.Y., Prystyazhnyuk S.A. Anthropogenous influence of Norilsk industrial area on plant vegetation cover of the tundra and forest tundra. Contemporary Problems of Ecology, 2014, vol. 7, no. 6, pp. 654-668.

34. Zhulidov A.V., Robarts R.D., Pavlov D.F., Kämäri J., Gurtovaya T.Y., Meriläinen J.J., Pospelov I.N. Long-term changes of heavy metal and sulphur concentrations in ecosystems of the Taymyr Peninsula (Russian Federation) North of the Norilsk Industrial Complex. Environmental Monitoring and Assessment, 2011, vol. 181 , no. 1-4, pp. 539-553.

35. Vinogradova A.A., Maksimenkov L.O., Pogarskii F.A. Changes in the atmospheric circulation and environmental pollution in Siberia from the industrial regions of Norilsk and the Urals in the early 21st century. Atmospheric and Oceanic Optics, 2009, vol. 22, no. 4, pp. 396-404.

36. Zhulidov A.V., Headley J.V., Robarts R.D., Nikanorov A.M. Ischenko A.A., Champ M.A. Concentrations of $\mathrm{Cd}, \mathrm{Pb}, \mathrm{Zn}$ and $\mathrm{Cu}$ in pristine wetlands of the Russian Arctic. Marine Pollution Bulletin, 1997, vol. 35, no. 7-12, pp. 242-251.

37. Zhulidov A.V., Headley J.V., Robarts R.D., Nikanorov A.M., Ischenko A.A., Champ M.A. Concentrations of $\mathrm{Cd}, \mathrm{Pb}, \mathrm{Zn}$ and $\mathrm{Cu}$ in contaminated wetlands of the Russian Arctic. Marine Pollution Bulletin, 1997, vol. 35, no. 7, pp. 252-259.

38. Gursky Y.N. Detection and evaluation of anthropogenic pollution on the basis of geochemical study of the interstitial waters of marine and freshwater sediments. Moscow University Geology Bulletin, 2017, vol. 72, no. 6, pp. 424-435.

39. Zakharov A.I., Zakharova L.N., Mitnik L.M. Monitoring of the Norilsk TPP-3 fuel tanks stability by means of radar interferometry techniq. Sovremennye problemy distantsionnogo zondirovaniya Zemli iz kosmosa, 2020, vol. 17, no. 5, pp. 281-285. In Rus.

40. Yakutseni S.P., Solov'ev I.A. Calculation of environmental damage as a result of an accident at a fuel depot in Norilsk. Geograficheskaya sreda i zhivye sistemy, 2020, no. 4, pp. 48-56. In Rus.

41. Troshko K.A., Denisov P.V., Lavrova O.Yu., Lupyan E.A., Medvedev A.A. Observation of the Ambarnaya River pollution resulting from the accident at the Norilsk Thermal Power Plant no. 
3 on May 29, 2020. Sovremennye problemy distantsionnogo zondirovaniya Zemli iz kosmosa, 2020, vol. 17, no. 3, pp. 267-274. In Rus.

42. Lezhenin A.A., Raputa V.F., Yaroslavtseva T.V. Numerical analysis of atmospheric circulation and pollution transfer in the environs of Norilsk industrial region. Atmospheric and Oceanic Optics, 2016, vol. 29, no. 6, pp. 565-569.

43. Zaslavskaya M.B., Erina O.N., Efimova L.E. Comparing the efficiency of river water quality parameterization by different methods under a significant human-induced impact. Geography and Natural Resources, 2019, vol. 40, no. 2, pp. 122-128.

44. Nosova O.V., Galishevskaya V.V., Karmanovskaya N.V. Monitoring vod otkrytykh vodoemov Norilskogo promyshlennogo rayona [Monitoring open water waters of the Norilsk industrial area]. Kultura. Nauka. Proizvodstvo, 2020, no. 5, pp. 80-85.

45. Mazlova E.A., Meritsidi I.A., Blinovskaya Ya.Yu., Razmakhnin K.K., Kulikova O.A. Advantages and disadvantages of oil sorbents for oil spill response at low temperatures. Zashchita okruzhayushchey sredy v neftegazovom komplekse, 2020, no. 6, pp. 55-60. In Rus.

46. Rusakov V.Y., Kuzmina T.G., Levitan M.A., Toropchenova E.S., Zhilkina A.V. Heavy metal distribution in the surface layer of bottom sediments of the Kara Sea. Geochemistry International, 2017, vol. 55, no. 12, pp. 1079-1089.

47. Ji X., Abakumov E., Xie X. Atmosphere-ocean exchange of heavy metals and polycyclic aromatic hydrocarbons in the Russian Arctic Ocean. Atmospheric Chemistry and Physics, 2019, vol. 19, no. 22, pp. 13789-13807.

48. Vinogradova A.A., Kotova E.I. Pollution of Russian Northern Seas with Heavy Metals: Comparison of Atmospheric Flux and River Flow. Izvestiya-Atmospheric and Ocean Physics, 2019, vol. 55, no. 7, pp. 695-704.

49. Agbalyan E., Krasnenko A., Shinkaruk E. Concentration of heavy metals and metalloids in the bottom sediments of the Vilkitsky Island's lakes (the Kara Sea). Actual Problems of Ecology and Environmental Management: Cooperation for Sustainable Development and Environmental Safety (APEEM 2020). E3S Web of Conferences. Moscow, Russia, April 23-24, 2020. Vol. 169, pp. 1-6.

50. Ponomareva T.V., Trefilova O.V., Bogorodskaya A.V. Shapchenkova O.A. Ecological and functional estimation of soil condition within the zone of technogenic impact of Norilsk industrial complex. Contemporary Problems of Ecology, 2014 vol. 7, no. 6, pp. 694-700

51. Vodyanitskii Y.N., Plekhanova I.O., Prokopovich E.V Savichev A.T. Soil contamination with emissions of non-ferrous metallurgical plants. Eurasian Soil Science, 2011, vol. 44, no. 2, pp. $217-226$.

52. Efremova T.T., Efremov S.P. Ecological and geochemical assessment of heavy-metal and sulfur pollution levels in hilly peatbogs of southern Taimyr. Contemporary Problems of Ecology, 2014, vol. 7, no. 6, pp. 685-693.

53. Kharuk V.I., Nilsson S., Samarskaia E. Anthropogenic and technogenic stress factors to forests in Siberia. IIASA Working Paper WP-96-104. Laxenburg, Austria, 1996. $104 \mathrm{p}$.

54. Karmanovskaya N.V., Smirnova A.T., Litovchenko V.I., Efa S.G Automated systems of ecological control in Norilsk. $2^{\text {nd }}$ International Scientific Conference on Advanced Technologies in Aerospace, Mechanical and Automation Engineering (MIST: Aerospace 2019. IOP Conference Series: Materials Science and Engineering. Krasnoyarsk, 18-21 November, 2021. Vol. 734, pp. $1-4$.

55. Karmanovskaya N.V., Bazelyanskaya T.P. Research of the ecological state of water bodies and soils in the industrial Arctic territories. Kultura. Nauka. Proizvodstvo, 2020, no. 6, pp. 74-78. In Rus.

56. Korets M.A., Ryzhkova V.A., Danilova I.V., Sukhinin A.I., Bartalev S.A. Forest disturbance assessment using satellite data of moderate and low resolution. In: Environmental Change in Siberia.
Advances in Global Change Research. Dordrecht, Springer, 2010. pp. 3-19.

57. Korets M.A., Ryzhkova V.A., Danilova I.V. GIS-based approaches to the assessment of the state of terrestrial ecosystems in the Norilsk Industrial Region. Contemporary Problems of Ecology, 2014, vol. 7, no. 6, pp. 643-653.

58. Bauduin S., Clarisse L., Clerbaux C., Hurtmans D., Coheur P.-F. IASI observations of sulfur dioxide $\left(\mathrm{SO}_{2}\right)$ in the boundary layer of Norilsk. Journal of Geophysical Research: Atmospheres, 2014, vol. 119, no. 7, pp. 253-263.

59. Zotin A., Zuev D., Kashkin V., Kurako M., Simonov K. Environmental risk zones mapping using satellite monitoring data. Procedia Computer Science, 2018, vol. 126, pp. 1597-1605.

60. Nikitenko A.A., Timofeev Y.M., Berezin I.A., Poberovskii A.V., Virolainen Y.A., Polyakov A.V. The analysis of OCO-2 satellite measurements of $\mathrm{CO}_{2}$ in the vicinity of Russian cities. Atmospheric and Oceanic Optics, 2020, vol. 33, no. 6, pp. 650-655.

61. Shevchuk A.V. Ecological and economic aspects of Arctic development. Nauchnye trudy Volnogo ekonomicheskogo obshchestva Rossii, 2020, vol. 226, no. 6, pp. 146-162. In Rus.

62. Rudakova L.V., Rudakov R.B. Obosnovanie osobogo podkhoda k pravovomu regulirovaniyu vozmeshcheniya ekonomicheskogo ushcherba ot ekologicheskikh narusheniy $\mathrm{v}$ Arkticheskikh rayonakh [Validation of especial approach to legal regulations of compensation of economic damage from ecological disturbance in Arctic regions]. III Uralskiy mezhdunarodny ekologicheskiy kongress. Ekologicheskaya bezopasnost promyshlennykh regionov [III Ural international ecological congress. Environmental safety of industrial regions]. Ekaterinburg, 25-31 May 2015. Ekaterinburg, SOO - MANEB, IE UrO RAN, UGGU Publ., 2015. pp. 252-256.

63. Leontev L.I., Tarasov A.V. Ecological problems of «Norilsk Nickel» and possible solutions. P. 3. Sulfur and its use. Ekologiya $i$ promyshlennost Rossii, 2017, vol. 21, no. 5, pp. 11-15. In Rus.

64. Leontev L.I., Tarasov A.V. Environmental issues of «Norilsk Nickel» and possible solutions. P. 2. Use and recovery of sulfur dioxide]. Ekologiya i promyshlennost Rossii, 2017, vol. 21, no. 4, pp. 20-25. In Rus.

65. Koptev D.P. Norilsk spill: lessons and consequences. Burenie $i$ neft, 2020, no. 7-8, pp. 3-9. In Rus.

66. Karmanovskaya N.V. Industrial and public environmental control in Norilsk. Ekologiya urbanizirovannykh territoriy, 2020, no. 2, pp. 94-99. In Rus.

67. Tsukerman V.A., Ivanov S.V. Management of the industrial waste when exploiting mineral resources of the Arctic. $17^{\text {th }}$ International Symposium on Solid Oxide Fuel Cells (SOFC-XVII). IOP Conference Series: Earth and Environmental Science, 18-23 July, 2020. Vol. 459, pp. 1-5.

68. Ekologicheskie problemy Arktiki [Ecological problems in Arctic]. 2021. Available at: https://arctic.narfu.ru/spisokliteratury/ekologiya/ekologicheskie-problemy-arktiki (accessed: 22 May 2021)

69. Activation-655 - oil spill in Russia. 2021. Available at: https://cgt.disasterscharter.org/en/655 (accessed: 22 May 2021).

70. Kharitonova G.N. Finansovye mekhanizmy i organizatsionnye modeli likvidatsii nakoplennogo ekologicheskogo ushcherba $\mathrm{v}$ rayonakh Kraynego Severa [Financial mechanisms and organizational models for eliminating cumulative ecological damage in Far North regions]. 5-ya Vserossiyskaya nauchnaya konferentsiya $s$ mezhdunarodnym uchastiem. Problemy ratsionalnogo ispolzovaniya prirodnogo i tekhnogennogo syrya Barents-regiona $v$ tekhnologii stroitelnykh $i$ tekhnicheskikh materialov $\left[5^{\text {th }}\right.$ All-Russian scientific conference with international participation. Problems of rational use of natural and technogenic raw materials of Barents Region in technology of building and technical materials]. Apatity, 12-15 November 2013. pp. 190-195.

Received: 25 May 2021. 


\section{Information about the authors}

Nikolay V. Yurkevich, Cand. Sc., senior researcher, Trofimuk Institute of Petroleum Geology and Geophysics, SB RAS.

Igor N. Eltsov, Dr. Sc., professor, Trofimuk Institute of Petroleum Geology and Geophysics, SB RAS.

Vadim N. Gureev, Cand. Sc., senior researcher, Trofimuk Institute of Petroleum Geology and Geophysics, SB RAS; assistant professor, Novosibirsk State Technical University.

Nikolay A. Mazov, Cand. Sc., head of the information analytical center, Trofimuk Institute of Petroleum Geology and Geophysics, SB RAS.

Nataliya V. Yurkevich, Cand. Sc., head of the laboratory, Trofimuk Institute of Petroleum Geology and Geophysics, SB RAS.

Aleksey V. Edelev, Cand. Sc., senior researcher, Trofimuk Institute of Petroleum Geology and Geophysics, SB RAS. 